\title{
International human rights procedures
}

Following the global atrocities of World War II, the Allies established criminal tribunals to prosecute perpetrators of wartime abuses and human rights atrocities. They also met with the Soviet Union at Dumbarton Oaks in Washington DC to discuss plans for establishing an international organization that would include methods for protecting human rights. However, by the time the United States (US) delegates arrived at Dumbarton Oaks they had decided to include only a general statement on human rights and were able to convince the British and Soviet delegates to include a brief statement in the United Nations (UN) Charter. ${ }^{1}$ After the Dumbarton Oaks Conference, nongovernmental organization (NGOs) worked to establish guidelines and an active role by the UN to promote and protect human rights. ${ }^{2}$ Eventually, the UN Charter was adopted in 1945 and it established human rights as a matter of concern. ${ }^{3}$ The General Assembly (GA) adopted the Universal Declaration of Human Rights in $1948,{ }^{4}$ which started the process of codifying human rights standards in the international arena. Ultimately, this effort resulted in three types of bodies overseeing the adoption of standards and their enforcement: the Charter-based bodies such as the GA and the bodies that report to it, the treaty-based bodies, established by treaties adopted by governments, and international criminal procedures, adopted at international conferences and then ratified by countries. This chapter will introduce the procedures for human rights promotion and protection by the Charter and treaty bodies and address the effects of their outcome documents. See Figure 1.1.

The international criminal procedures will be addressed in Chapter 3 .

\footnotetext{
1 David Weissbrodt and Connie de la Vega, International Human Rights: An Introduction (Penn Press 2007), p.23.

2 Ibid. at pp.23-4.

3 Charter of the United Nations, June 26, 1945, 59 Stat. 1031, T.S. 993, 3 Bevans 1153 (entered into force Oct. 24, 1945) (see e.g., Preamble and Articles 1, 55, and 56).

4 GA Res 217 (III) A, Universal Declaration of Human Rights 71, UN Doc A/810 (Dec. 10, 1948).
} 


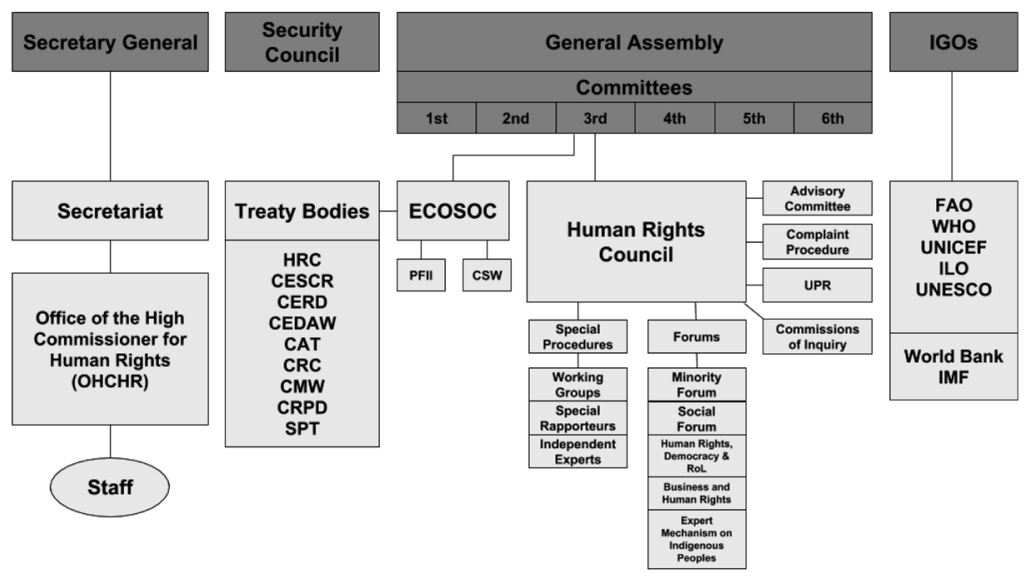

Figure 1.1 United Nations Human Rights Bodies

\section{A. Charter-based procedures}

The GA was established by Chapters III and IV of the UN Charter. It is the most representative decision-making organ of the UN since most of the countries of the world are members and are entitled to vote. ${ }^{5}$ It is the body that gives final approval to human rights treaties, declarations, and other instruments that are initiated by its subsidiary bodies, such as the Human Rights Council (the Council) which has reported directly to the GA since it replaced the Commission of Human Rights in 2006. It also oversees the Economic and Social Council (ECOSOC) which is the body that monitors the Commission on the Status of Women. This chapter will address the procedures of the Council and certain ECOSOC procedures such as the Commission of the Status of Women (CSW), the Permanent Forum on Indigenous Issues (PFII), and certain specialized agencies that report to ECOSOC such as the International Labour Organization (ILO) and the UN Educational, Scientific, and Cultural Organization (UNESCO). These bodies allow for the greatest level of NGO participation as well as opportunities to influence

5 The countries that are not members are: the Vatican City, which has full observer status; the Cook Islands and Niue, who by choice let New Zealand represent them; Western Sahara, whose legal status continues in dispute; the Occupied Palestinian Territory, which is an observer as a nonmember entity; Kosovo, which is not recognized as a separate entity; and the Republic of Taiwan. For a list of the member states and reference to the status of the Holy See and Palestine, see UN Member States, www.un.org/en/member-states/index.html. 
the development of human rights standards and address violations of human rights by countries. Participation at the Council and the Commission on the Status of Women requires ECOSOC accreditation of the NGO being represented, while participation at some of the procedures such as the Universal Periodic Review (UPR), the special procedures, and the forums do not. The accreditation procedures will be addressed at the end of this chapter. As is the case with participation in most international procedures, their use is most successful if it is part of an overall strategy for addressing particular human rights issues, which can include both addressing violations in particular countries as well as further developing international human rights standards.

\section{Human Rights Council}

In 2006, the Council replaced the Commission on Human Rights, which had been created by ECOSOC under the UN Charter Article 68 to carry out its work on human rights. Rather than getting approval from ECOSOC first, the Council reports directly to the GA, making it more feasible to have its resolutions approved more quickly. The 47 members of the Council are elected by a majority vote of the GA. The Council meets three times a year - for four weeks in March and three weeks in June and September. It retained the procedures of the Commission for the participation of NGOs, which are some of the most open at the UN. The Council is considering reducing the number of sessions per year.

The Council continued the mandates of the special procedures created by the Commission as well as the 1503 complaint procedure. Both will be discussed below. One concern about the Commission was that it was selective regarding the countries it decided to call out in resolutions. To address this concern, it established the Universal Periodic Review (UPR) to monitor the human rights compliance by all countries on a rotating schedule. This procedure relies a great deal on information submitted by NGOs.

This section will now cover the general procedures for addressing human rights issues, which include not only how NGOs can raise violations before the body but how they can be involved in the process of drafting resolutions on both theme and country human rights issues. How NGOs can interact with the Special Rapporteurs and Working Groups, the UPR and the 1503 complaint procedure will also be addressed. The latter will include admissibility requirements and 
outcomes from the process. Country-specific investigation procedures, such as Commissions of Inquiry (COIs) and Fact-finding Missions (FFMs) to promote accountability, will also be covered.

\section{a. Main sessions}

The Council's meetings include Main Sessions as well as side events and resolution drafting sessions. The first step for participation in any of these at the Council is to get ECOSOC accreditation. The details of this are discussed below.

The next step is to look at the Programme of Work of the Council for its sessions. ${ }^{6}$ The Council issues its general schedule for the following year in December but advocates can look at the schedule for the previous year to get a general idea of the topics the Council will consider and which session. While it is not always guaranteed that the schedule will be identical the following year, it is generally followed. It is important to review both when the topic will be addressed by the Council and when it will consider resolutions on the topic. ${ }^{7}$ Generally, resolutions are considered at the same session that the topic is addressed on the floor, but not always. Also, the Council may schedule a panel on a particular topic but not address the issue in a resolution until another session. One example is the issue of the death penalty: on March 1, 2017 during the 34th session on of the Human Rights Council there was a high-level panel discussion on the death penalty, but no resolution that session. ${ }^{8}$ The resolution on the death penalty was addressed at the 36 th session in September. ${ }^{9}$

Advocates also need to decide if they want to work on country-based or theme-based resolutions. Outside the UPR, agenda items and resolutions focused on human rights in specific countries are difficult to get passed as they are very political. For example, at the 34th session

\footnotetext{
6 This is available before each session on the Extranet, a link that includes documents for each Council session and can be found on the UN Human Rights Council's website for each of the sessions: http://www.ohchr.org/EN/HRBodies/HRC/Pages/HRCIndex.aspx.

7 This information is also available on the Programme of Work available for each session on the Extranet or on the UN Human Rights Council's website for each session, http://www.ohchr.org/ EN/HRBodies/HRC/Pages/Sessions.aspx.

8 Report of the Human Rights Council on its 34th session, 63, UN Doc A/HRC/34/2 (advance unedited version) (June 14, 2018).

9 Human Rights Council, The Question of the Death Penalty, UN Doc A/HRC/36/L.17 (Sep. 29, 2017).
} 
in March 2017 the countries discussed were the Democratic People's Republic of Korea (DPRK), Eritrea, Islamic Republic of Iran, Myanmar, and the Syrian Arab Republic; ${ }^{10}$ at the 35th session in June 2017 the specific countries discussed were Belarus, the Democratic Republic of Congo, with follow-up to Eritrea, Myanmar, and the Syrian Arab Republic; ${ }^{11}$ and at the 36 th session in September 2017, the specific countries discussed were South Sudan, Burundi, and again Myanmar. ${ }^{12}$ In comparison to these mandates on ten countries, there were over 44 theme procedures in effect in $2017 .{ }^{13}$ It is easier to get a specific practice addressed in a theme resolution even if it only affects a few countries. Advocates taking this route can still refer to the countries as examples in their written and oral statements when urging the Council to address the practice in a theme resolution.

Once an agenda item is found to address the specific topic, the resolutions from prior sessions setting the topic should be researched. The trend in the past few years has been to define a specific aspect of the issue at the session. For example, the rights of the child agenda item used to be broad and allowed discussion on a variety of issues related to children's rights. ${ }^{14}$ Recently, however, the Resolution on the Rights of the Child will set out a very specific topic for discussion at the next session where it will be heard ${ }^{15}$ and the resolution at that session will focus on that topic. For example, at the 34th session, the resolution on the rights of the child specifically requested the High Commissioner to work with all UN organizations and Special Rapporteurs for a report on the theme of 'Protecting the rights of the

10 Human Rights Council, Programme of Work for the 34th Session of the Human Rights Council (27 February-24 March 2017), A/HRC/34/1 (Mar. 16, 2017), available on the Extranet, see note 6 above.

11 Human Rights Council, Programme of Work for the 35th Session of the Human Rights Council (2-23 June 2017), A/HRC/35/1 (June 20, 2017), available on the Extranet, see note 6 above.

12 Human Rights Council, Programme of Work for the 36th Session of the Human Rights Council (11-29 September 2017), A/HRC/36/1 (Sep. 26, 2017), available on the Extranet, see note 6 above.

13 Special Procedures of the Human Rights Council, http://www.ohchr.org/EN/HRBodies/SP/ Pages/Welcomepage.aspx; for an introduction and case studies of the special procedures, see Humberto Cantú Rivera (ed.), The Special Procedures of the Human Rights Council: A Brief Look From the Inside and Perspectives from Outside (Intersentia 2015).

14 Human Rights Council, Rights of the Child, 7th Session, UN Doc A/HRC/RES/7/29 (Mar. 28, 2003).

15 See e.g., Human Rights Council Res. 31/7, Rights of the child: information and communications technologies and child sexual exploitation, UN Doc A/HRC/RES/31/7 (Apr. 20, 2016); Human Rights Council, Rights of the child: towards better investment in the rights of the child, UN Doc A/HRC/RES/28/19 (Apr. 7, 2015). 
child in humanitarian situations' for the 37 th session taking place the following year. ${ }^{16}$

Another example is the development of the right to privacy, which is recognized in Article 17 of the International Covenant on Civil and Political Rights. ${ }^{17}$ The Council has recognized several aspects of that right, including the right to privacy in indigenous cultures' religious practices, ${ }^{18}$ children's right to privacy, ${ }^{19}$ and the right to privacy for survivors of sexual abuse and violence, ${ }^{20}$ but in 2016, it decided that it would address the issue of digital privacy at its 34 th session. ${ }^{21} \mathrm{~A}$ representative of Human Rights Advocates, an ECOSOC accredited NGO, participated at the drafting meetings at the 34th session and was able to advocate inclusion of language regarding the effect that metadata can have on that right. ${ }^{22}$ The resolution included language on metadata in the Preamble and called upon business enterprises to meet their responsibility to respect human rights in the collection, use, sharing, and retention of data in Paragraph $8 .{ }^{23}$ This resolution can now be the basis for further assessment of how to protect the right to privacy in the digital age, especially in relation to its use by private actors. ${ }^{24}$

16 Human Rights Council, Rights of the Child: protection of the rights of the child in implementation of the 2030 Agenda for Sustainable Development, UN Doc A/HRC/34/16, 29 (March 24, 2017).

17 International Covenant on Civil and Political Rights, GA Res 2200A (XXI), 21 GAOR Supp. (No. 16) at 52, UN Doc A/6316 (1966), 999 UNTS 171, entered into force March 23, 1976.

18 Rep of the Human Rights Council, United Nations Declaration on the Rights of Indigenous Peoples, UN Doc A/61/53, at 20 (2006).

19 Rep of the Human Rights Council, Rights of the Child: the fight against sexual violence against children, UN Doc A/65/53, at 125 (2010).

20 Rep of the Human Rights Council, Accelerating efforts to eliminate all forms of violence against women: preventing and responding to rape and other forms of sexual violence, UN Doc A/68/53, at 100 (2013).

21 See e.g., Human Rights Council Res. 28/16, The right to privacy in the digital age, UN Doc A/ HRC/RES/21/16 (Apr. 1, 2015); Joseph A. Cannataci (Special Rapporteur on the Right to Privacy) Rep. of the Special Rapporteur on the Right to Privacy, UN Doc A/HRC/31/64 (Nov. 24, 2016).

22 Nicole Beckley, The Right to Privacy: Compromise in the Resolution Process, Vol. 69 Human Rights Advocates Newsletter p.9 (Summer 2017); written statement submitted by Human Rights Advocates Inc. (a non-governmental organization in special consultative process), Right to Privacy: Mass Surveillance and Meta-Data Retention by States, UN Doc A/HRC/34/NGO/49 (Feb. 15, 2017); Human Rights Advocates, The Right to Privacy: Mass Surveillance and Metadata Retention by States (2017) http://www.humanrightsadvocates.org/wp-content/uploads/2017/o4/ Right-to-Privacy-Mass-Surveillance-and-Metadata-Retention-by-States.pdf.

23 HRC Res 34/7, The Rights of Privacy in the Digital Age, Supp. No. 53 UN Doc A/72/53, at 37 (Aug. $8,2017)$.

24. Ibid., 5 (f). 
One way to give attention to a particular issue at a Council session is to submit a written statement of 1500 words. These statements become part of the record for the session and can be referred to when advocating on the topic, both during and outside the session. They are also useful for creating a record on the topics covered. These are usually due three weeks before the session starts. NGOs can also speak before the Council during the discussion of the agenda item. All NGOs' oral statements need to be two minutes or shorter - the President of the Council will often turn off the microphone if the speaker goes over time regardless of whether it is a government or NGO representative. NGOs are given an opportunity to sign up to speak under all agenda items but have to prioritize the issues when signing up. The order requested will likely result in being able to speak on the top two priorities for the NGO. A statement with five or more co-sponsors will also be given a preference at the top of the NGO speakers' list for each agenda item.

At the end of each agenda item there is a General Debate when all delegations who have requested to speak will be allowed to do so. This includes NGOs. However, the times when this happens are not ideal. For example, the General Debate on Agenda Item 3 is often held on Friday afternoon when the main country delegates are not in the room. Nonetheless, being able to make an oral statement can bring attention to a human rights issue or violations taking place in countries and it becomes part of the record for the session. Further, it allows NGOs to raise issues that are not covered by the agenda.

Many agenda items will consist of theme topics discussed in Interactive Dialogues (IDs) usually clustered in groups of two presentations by the Special Rapporteurs or Working Groups. These are referred to as the Special Procedures. Examples from the 34th session include: Interactive Dialogues of the Special Rapporteurs on Truth, Justice and Freedom of Religion; the Special Representatives of the Secretary-General (SRSG) for Violence Against Children and Children in Armed Conflict; Special Rapporteurs on Privacy and the Sale of Children; Special Rapporteurs on Human Rights Defenders and Torture; Special Rapporteurs on Foreign Debt and Adequate Housing, and Special Rapporteurs on the Environment and Food. ${ }^{25}$ The sessions that have been held in June and September each year typically have

25 Programme of Work for the 34th Session of the Human Rights Council (27 February-24 March 2017), A/HRC/34/1 (Mar. 16, 2017), available on the Extranet, supra note 6. 
fewer Interactive Dialogues. For examples at the 35th session in June 2017 there was an ID with the Special Rapporteurs on Independence of Judges and Lawyers and Violence Against Women, and two IDs dedicated to the Special Rapporteur on Racism. ${ }^{26}$ During the 36th session in September, 2017 there was an ID with the Special Rapporteurs for Contemporary Forms of Slavery and the Working Group on Arbitrary Detention; an ID with the Independent Expert on the International Order and the Special Rapporteur on Coercive Measures; and an ID with the Special Rapporteur on Indigenous Peoples, and another with the Special Rapporteur on the Right to Development. ${ }^{27}$ All the statements are video recorded and can be watched during and after the sessions on UN Web TV.

\section{b. Resolution drafting sessions}

During the Council session, drafting meetings for resolutions will also take place. Resolutions are the outcome documents of the Council. They are referred to the GA in the report of the Council. They often lead to resolutions addressing the particular topic by the GA.

The initial drafting sessions by the countries sponsoring the resolution are private and can only be attended by those countries. However, once the resolution is made public and the sessions to discuss the language are scheduled, delegates from all countries and NGOs can attend. These meetings will take place outside the main meeting room. Chairs of the sessions have different rules for when NGOs can intervene at drafting sessions. Usually resolutions are discussed paragraph by paragraph or in a group of paragraphs and the general practice is to let the NGOs make comments after the country delegates. Some Chairs only give the floor to the NGOs at the end of the session. It is always best to ask the Chairs of the drafting session what procedure they will use. Once the resolution is submitted to the full Council and it is discussed on the floor, NGOs are no longer allowed to intervene orally; however, they can still discuss the language with delegates during breaks or outside the main meeting room.

26 Programme of Work for the 35th Session of the Human Rights Council (2-23 June 2017), A/HRC/35/1 (June 20, 2017), available on the Extranet, supra note 6.

27 Programme of Work for the 36th Session of the Human Rights Council (11-29 September 2017), A/HRC/36/1 (Sep. 26, 2017), available on the Extranet, supra note 6. 
In order to be effective, participation in the drafting of resolutions under the theme procedures should be part of a larger advocacy project. As discussed below, resolutions on specific countries under both the regular resolution drafting process and the UPR reporting process are most effective if they are used to promote national advocacy goals. This can include addressing a particular violation or ending a specific practice, such as life without parole sentences. This is the same for theme-based resolutions.

Once the resolutions are adopted, they can be used to support litigation and legislative efforts at the national level. One example of this was the decision by the US Supreme Court that referred to international standards in holding that the death penalty for juvenile offenders violated the US Constitution. ${ }^{28}$ Human Rights Advocates had advocated inclusion of the prohibition of the use of the death penalty for offenders under the age of 18 in the resolutions at the Commission on Human Rights and was one of the amici curiae who filed a brief in Roper v. Simmons. The brief included reference to the Commission on Human Rights resolutions from 1997 to 2004 calling on States 'not to impose [the death penalty] for crimes committed by persons below 18 years of age'. ${ }^{29}$ The US Supreme Court struck down juvenile sentences referring to both the evolution of international law and practice in the global community as instructive for its interpretation of the Eighth Amendment's prohibition of 'cruel and unusual punishment'. ${ }^{30}$ The US Supreme Court also referred to the Convention on the Rights of the Child in addressing the constitutionality of life without parole sentences for non-homicide crimes by juvenile offenders. ${ }^{31}$ Human Rights Advocates had also advocated inclusion of the prohibition of life without parole sentences for juvenile offenders in resolutions at the Human Rights Council and was one of the amicus curiae in the brief that referred to those resolutions prohibiting life without parole sentences for persons under 18 years of age when they committed their crime. ${ }^{32}$

As a matter of strategy, it is always better to talk to delegates about including language in resolutions before they are discussed by the full

28 Roper v. Simmons, 543 U.S. 551, 576-77 (2005) (No. 03-633), 2004 WL 1628523.

29 Brief of the Human Rights Committee of the Bar of England and Wales, et al. as Amici Curiae

Supporting Respondents, at p.14-'15, Roper v. Simmons, ibid.

30 Roper v. Simmons, ibid., at pp.575-8.

31 Graham v. Florida, 560 U.S. 48, 81 (2010).

32 Brief for Amnesty International, et al, as Amici Curiae Supporting Petitioners, at pp.20-21 (2009),

Graham v. Florida, Sullivan v. Florida, Case Nos. 08-7412, 08-7621, 2009 WL 2219304. 
body. As Nigel Rodley, a founder of Amnesty International and former Special Rapporteur Against Torture, has noted:

Certainly I've always found in any drafting exercise, whether on torture or anything else, it's always much better if you can make sure that any text being discussed already has what you want in it. The function of the NGOs is then to defend what is there rather than to be perceived in the radical role of trying to get new and difficult material in. ${ }^{33}$

It is always helpful to work with other NGOs on issues. However, it is important to keep in mind that some NGOs are sponsored by governments for the purpose of finding out what NGOs are doing. These groups are referred to as GONGOs, an informal term that refers to government sponsored NGOs. ${ }^{34}$ Thus, it is important that NGOs investigate groups that they are not familiar with before working with them.

\section{c. Universal Periodic Review}

A separate procedure that NGOs can participate in at the main sessions of the Council is the UPR. Under GA Resolution 60/251, the Council was authorized to establish the UPR in order to assess the fulfillment of each UN Member State's human rights violations. ${ }^{35}$ The Council will review approximately 14 countries each session. ${ }^{36} \mathrm{~A}$ 'troika' of three countries will be appointed to prepare the outcome reports for the countries at each session. The Office of the UN High Commissioner for Human Rights (OHCHR) compiles the reports that will form the basis of review which include the Stakeholder's Summary. Reports on the countries by NGOs are welcome and must be filed at least six months

33 Presentation by Nigel Rodley, Torture, Human Rights: From Practice to Policy: Proceedings of a Research Workshop, Gerald R. Ford School of Public Policy, University of Michigan, October 2010, at pp.8-9 (Carrie Booth Walling and Susan Waltz eds., 2011), https://deepblue.lib.umich. edu/bitstream/handle/2027.42/89426/PRACTICE_TO_POLICY.pdf?sequence $=4$ \&isAllowed $=y$.

34. See generally, Moises Naim, 'What is a Gongo?', Foreign Policy, Oct. 13, 2009, https://foreignpolicy.com/2009/10/13/what-is-a-gongo/; International Justice Resource Center, Advocacy before the African Human Rights System: A Manual for Attorneys and Advocates, at 6, IJRC.ORG (Oct. 2017), https://ijrcenter.org/wp-content/uploads/2017/11/2.-African-Human-Rights-SystemManual.pdf (for a discussion on how to address this issue in the African context).

35 GA Res 6o/251, 5(e), UN Doc A/RES/60/251 (Apr. 3, 2006).

36 See the Human Rights Council Universal Periodic Review Calendar of reviews for the 3rd cycle (2017-21) for accurate calendar updates, http://www.ohchr.org/EN/HRBodies/UPR/Pages/ UPRMain.aspx; see also 'A Practical Guide for Civil Society, Universal Periodic Review,' http:// www.ohchr.org/EN/HRBodies/UPR/Documents/PracticalGuideCivilSociety.pdf. 
before the session begins. ${ }^{37}$ There are page limits of five pages for individual submissions and ten pages for group submissions. Reports by NGOs can cover the general human rights situation in a country or specific practices. The decision on how much to cover depends on the resources of the NGO both to prepare the report and to advocate at the session before the Council. The reports by the NGOs will be available during the review. ${ }^{38}$ The latter will include a summary of the discussions, the questions and comments, recommendations, and responses by the countries being reviewed. The outcome reports of the UPR process can be useful for persuading countries to address specific issues in their national agenda. Further, NGOs can use the outcome reports in their advocacy efforts at the national level, which can include raising awareness, promoting legislation, or supporting litigation.

NGOs are able to observe the UPR proceedings without making oral statements. NGOs may organize information meetings on the UPR Process, for the purpose of sharing information and best practices. ${ }^{39}$ NGOs are encouraged to inform and involve States under review in these meetings. ${ }^{40}$ NGO information meetings are generally open to everyone present at the UPR session where NGOs may present information about a State under review. ${ }^{41}$ One advocacy goal is to get members of the Council to attend the information meetings, in particular delegates of the troika for the country involved, so that they are informed of the human rights situation in the country being reviewed under the procedure and the information is included in the outcome report. Since the review is peer to peer, the advocacy goal should be to convince Member States to raise a recommendation during the UPR session. State delegates only have two to three minutes to raise recommendations during the UPR session so it is useful to coordinate these efforts. Advocates should also be aware that recommendations raised by allied States and States from a particular region or regional groupings, as those are more likely to be accepted by the State under review. The outcome report then can be used in national advocacy efforts.

37 See Tentative deadlines for 'Other Stakeholders' (and UN entities) to submit written contributions, OHCHR, http://www.ohchr.org/EN/HRBodies/UPR/Pages/NgosNhris.aspx.

38 See Basic Facts about the UPR, OHCHR, https://www.ohchr.org/EN/HRBodies/UPR/Pages/ BasicFacts.aspx (last visited Aug. 25, 2018).

39 OHCHR, A Practical Guide for Civil Society, Universal Periodic Review, at 4 (July 2014), OHCHR, http://www.ohchr.org/EN/HRBodies/UPR/Documents/PracticalGuideCivilSociety.pdf.

40 Ibid. at p.7.

41 Ibid. at p.9. 
It is helpful to coordinate efforts of NGOs to have focused advocacy on a specific topic. One example is a stakeholder submission prepared by three NGOs in 2014 on the use of juvenile life without parole in the US. ${ }^{42}$ The three organizations had experience addressing the topic in various contexts, including under the prior UPR review of the US. The joint advocacy in 2014 on this topic resulted in a paragraph on juvenile life without parole in the UPR outcome report on the US by the Council. ${ }^{43}$

Another example of successful advocacy under the UPR were the efforts of several NGOs concerned with urban refugees and asylum seekers in Thailand who had little protection against human rights violations. Urban refugees remain in constant fear of being placed in immigration detention where they stay in deplorable conditions for prolonged periods until either their immigration status is somehow normalized or until they elect to return to their countries of origin. ${ }^{44}$

In 2015, human rights defenders engaged in a rare opportunity to address human rights concerns of urban refugees and asylum seekers directly with the Thai Government through Thailand's second UPR. Among them, Asylum Access, an international refugee rights NGO, formed a coalition with six other refugee response organizations working directly with asylum seekers, refugees and migrants throughout Thailand. They prepared a stakeholder submission for the UPR outlining concerns across eight thematic human rights areas, including allegations detailing how the conditions of Thailand's immigration detention centers fall well below international standards. ${ }^{45}$

42 Human Rights Advocates, the Campaign for the Fair Sentencing of Youth, and Human Rights Watch, Updated Submission for the UPR regarding life-without-the possibility of release or parole sentences for children in the United States (2014), www.humanrightsadvocates.org/advocacy-atthe-un.

43 Summary prepared by the Office of the United Nations High Commission for Human Rights in accordance with para 15 (c) of the annex to Human Rights Council resolution $5 / 1$ and para 5 of the annex to council resolution 16/21, United States of American, 54, UN Doc A/HRC/WG.6/22/ USA/3 (Feb. 16, 2015).

44. 'Thailand: Implement Commitments to Protect Refugee Rights: End Detention, Forcible Returns of Refugees', Human Rights Watch (Jul. 6, 2017 8:ooAM EDT), https://www.hrw.org/ news/2017/07/06/thailand-implement-commitments-protect-refugee-rights.

45 Rep of Asylum Access, Asia Pacific Refugee Rights Network (APRRN), Fortify Rights, the Human Rights Development Foundation (HRDF), Jesuit Refugee Service (JRS), Migrant Working Group (MWG), and People's Empowerment Foundation (PEF) for consideration in the Kingdom of Thailand's Universal Periodic Review-2nd Cycle (Sept. 21, 2015), https://uprdoc.ohchr.org/ uprweb/downloadfile.aspx?filename $=2675 \&$ file $=$ EnglishTranslation. 
Following submission of their stakeholder report, Asylum Access and its coalition joined other human rights defenders throughout Thailand in a nearly year-long advocacy campaign targeting UN Member States. Their goal was to raise awareness about the human rights situation and urge Member States to issue relevant recommendations during Thailand's review in 2016. With the help of UPR Info, an organization that facilitates civil society engagement in the UPR process, NGOs disseminated short notes summarizing their submissions and organized briefing sessions with both embassies in Thailand and their Permanent Missions in Geneva. ${ }^{46}$

Asylum Access and its coalition targeted their advocacy at Member States who had previously raised recommendations relating to refugees' and asylum seekers' rights in earlier UPR sessions. They held bilateral meetings with embassies after the briefing sessions to lobby for their support during Thailand's review. Their advocacy was bolstered in part by OHCHR's Summary of Stakeholder Submissions, one of the three UN documents that frame the basis of each country's review under the UPR. The report cited many of the claims raised in Asylum Access's stakeholder submission, including allegations that 'conditions of detention centers fell below international standards since they are often overcrowded, and lack access to adequate healthcare services and religious and cultural accommodations' ${ }^{47}$

Their advocacy was successful as nearly a dozen States raised recommendations similar to those reflected in Asylum Access's stakeholder submission. Ultimately, however, the Thai Government accepted only a few of these recommendations, among them, those raised by both the Indian and Paraguayan delegations calling on the Government of Thailand to address the harsh living conditions in immigration detention centers. ${ }^{48}$

\footnotetext{
46 'Thai Voices from the Ground: Pre-sessions on Thailand held in Bangkok', UPR Info (Mar. 24, 2016), https://www.upr-info.org/en/news/thai-voices-from-the-ground-pre-sessions-on-thailand -held-in-bangkok.

47 HRC Working Group on the Universal Periodic Review, Twenty-Fifth Session held May 2-13, 2016, Summary Prepared by the Office of the United Nations High Commissioner for Human Rights in accordance with Paragraph 15 (c) of the Annex to Human Rights Council Resolution 5/1 and Paragraph 5 of the Annex to Council Resolution 16/21, Thailand, 21, A/HRC/WG.6/25/ THA/3 (Feb. 23, 2016).

48 Ibid. at 159.79 and 158.80 .
} 
In the months following the end of Thailand's second UPR, NGOs continued working in coalition and partnered with Thailand's National Human Rights Institution to prepare a draft implementation strategy detailing how the Thai Government should realize those recommendations it had committed itself toward implementing. NGOs prepared additional briefings for the media, embassies in Bangkok and Thai Government officials in order to raise consciousness of the outcome of Thailand's engagement with these UN mechanisms and to share their draft implementation strategy. After a series of meetings with Thailand's Ministry of Justice, which was charged with developing the government's National Human Rights Plan of Action, NGOs were able to secure details on how the government plans to implement many of those voluntary commitments during the four and a half years until its next UPR session. ${ }^{49}$

With regard to Thailand's commitment to improve the conditions of immigration detention centers, the government detailed plans to finance and build a new detention facility better capable of serving the large and diverse population of detained asylum seekers, refugees and migrants. ${ }^{50}$ While efforts are still in place towards ending policies resulting in arbitrary detention of vulnerable populations, the Thai Government's specific commitments to bring the conditions of immigration detention centers in line with international standards demonstrates the positive impact NGOs can have in leveraging the UPR mechanism to improve the human rights situation in reality.

The advocacy on the UPR in Thailand also exemplifies how it is not sufficient to simply advocate at the Human Rights Council and its subsidiary bodies. Efforts before and after the UPR process were critical for improving the human rights of the refugees and asylum seekers in that country. The most effective use of the UN procedures when dealing with country-specific issues is to make it part of a larger advocacy effort that includes both national and international components.

Given the volume of information considered in preparation for each State's UPR and the frequency of review, the OHCHR places specific

49 Human Rights Committee, Addendum, Replies of Thailand to the List of Issues [in Relation to the Second Periodic Report of Thailand], 131, UN Doc CCPR/C/THA/Q/2/Add.1 (Nov. 15, 2016). 50 Amnesty International, Between a Rock and a Hard Place: Thailand's Refugee Policies Violate the Principle of Non-Refoulement (Sept. 19, 2017), https://www.amnestyusa.org/wp-content/ uploads/2017/o9/2017.09.19-Between-a-Rock-and-a-Hard-Place-LOW-RES.pdf. 
guidelines on reports received by NGOs. ${ }^{51}$ In advance of the UPR's third cycle, the OHCHR updated its technical guidelines for submissions made by 'other stakeholders' ${ }^{52}$ The guidelines reiterate formatting constraints, such as: word limits of 2815 words for a single organization and 5630 words for a joint submission by two or more organizations; deadlines, six months prior to the review; and that the preferred languages of submissions being French, English, or Spanish. ${ }^{53}$ The OHCHR has also prepared matrices to help NGOs evaluate the implementation of recommendations issued to each State during previous UPR cycles and identify 'challenges or needs of technical cooperation' where recommendations have not been implemented. ${ }^{54}$ Matrices for each State can be downloaded on the UPR section of the UN's website and should accompany written submissions. ${ }^{55}$ Advocates should reference the 'Universal Periodic Review (Third Cycle): Information and guidelines for relevant stakeholders' written submissions' for a complete list of guidelines 'other stakeholders' should consider in drafting a UPR submission. ${ }^{56}$

\section{d. Special Procedures mechanisms}

In addition to participating in the process of establishing the Special Procedures mandates, both in theme and country resolutions, NGOs can participate in the carrying out of the mandates of the Special Rapporteurs, Independent Experts, and Working Groups. This advocacy can include lobbying for country visits, filing communications, filing urgent appeals, and contributing to thematic reports. The reports and complaints are filed with each mandate holder. Advocates can also participate in their country visits by helping to organize them or by testifying during the public sessions.

51 Office of the High Comm'r for Human Rights, Universal Periodic Review (Third Cycle): Info. and Guidelines for Relevant Stakeholders' Written Submissions (2017), OHCHR, https://www.ohchr. org/Documents/HRBodies/UPR/TechnicalGuidelines3rdCycle.docx [hereinafter OHCHR UPR 3rd Cycle Info. and Guidelines].

52 Ibid.

53 Ibid., g9 11, 13, 20.

54 OHCHR, 3rd UPR cycle: contributions and participation of 'other stakeholders' in the UPR, OHCHR, https://www.ohchr.org/EN/HRBodies/UPR/Pages/NgosNhris.aspx (last visited July 10, 2018) [hereinafter OHCHR UPR 3rd Cycle Contributions and Participation]; OHCHR UPR 3rd Cycle Info. and Guidelines, supra note 51.

55 OHCHR UPR 3rd Cycle Contributions and Participation, ibid.

56 OHCHR UPR 3rd Cycle Info. and Guidelines, supra note 51. 
Special Rapporteurs and Independent Experts are individuals appointed to address a specific issue or country. Special Rapporteurs have more resources available to carry out their mandates than the Independent Experts, but both can bring attention to the issue or country through their reports to the Council. The Working Groups usually consist of five members representing the five Regional Groups and thus have more resources to address the thematic issue of their mandate. ${ }^{57}$

The Special Rapporteurs, Independent Experts and Working Groups can receive information related to their mandates through the OHCHR. They prepare reports related to their topics which cover both civil and political rights as well as economic, social and cultural rights. They can send communications to States and generally undertake two country visits every year with the permission of the governments involved. They prepare reports with their findings and recommendations. NGOs provide information to the special procedures mandate holders and can also help organize their visits to the countries they visit.

Because the staff at the OHCHR is overworked, it is important to be focused about which mandate holders to send the information to. If the communication concerns more than one mandate holder, it is best to send the information to each one separately and set out the information clearly and concisely. One group of advocates for refugees and asylum seekers has prepared a list for advocates using these procedures to follow in order to get a response from the mandate holders. ${ }^{58}$ It includes listing the following information clearly:
(a) to whom the communication is addressed;
(b) who is submitting the information;
(c) which country the allegation is about;

57 For a recent book covering various aspects of the Special Procedures work, see Aoife Nolan, Rosa Freedman and Thérèse Murphy (eds), The United Nations Special Procedure System (Brill Nijhof 2017).

58 Camille Giffard annd Megan Hrle, 'The United Nations Charter-Based Mechanisms', in Joan Fitzpatrick (ed.), Human Rights Protections for Refugees, Asylum-Seekers, and Internally Displaced Persons: A Guide to International Mechanisms (Ardsley, NY: Transnational Publishers 2002) [updated in 2008 to take into account the Human Rights Council]. 
(d) the purpose of the information and whether urgent action is required. ${ }^{59}$

The communication should be submitted through the online portal at https://spsubmission.ohchr.org/.

The Special Procedures do not have enough resources to acknowledge receipt of all the communications and usually will only respond to the person or group making the submission if the government involved in the allegation sends a reply to the OHCHR. In order to find out if the information has been acted on, it is best to read the Communication Report posted in advance of the next Council session.

Some Special Procedures have urgent appeal procedures that can be used to intervene where an individual is 'at risk of serious human rights violations' ${ }^{60}$ In preparing these submissions, advocates should avoid last minute interventions; provide as many details as possible about the imminent action; provide details about the domestic remedies that have been used; and establish that the individual is at risk. ${ }^{61}$

Use of these procedures is most effective if it is part of a larger advocacy project. These include creating a strategy, building relationships with other NGOs, working year round to cultivate relationships with foreign offices and the Special Rapporteurs, and lobbying delegates specifically. ${ }^{62}$

The goals ultimately can include mobilizing shame by raising awareness about the violations being addressed, getting resolutions passed on specific countries, and having a mandate holder appointed to deal with a specific set of rights or country situation. The President of the Council can issue a statement about a particular country. These tend to present a watered-down version of the violations involved, but again they can be part of the mobilization of shame strategy. As such, this

59 Ibid. For a more detailed discussion on what to include in the communications, see Human Rights Institute, Colombia Law School, Engaging UN Special Procedures to Advance Human Rights at Home: A Guide for US Advocates, at p.22 (July 2015), https://web.law.columbia.edu/sites/default/ files/microsites/human-rights-institute/files/special_rapporteurs_report_final.pdf.

6o David Weissbrodt, International Human Rights: Law, Policy, and Process (5th edn. forthcoming 2018) (manuscript at p.34).

61 Ibid.

62 Ibid. at pp.35-6. 
can ultimately help pressure governments to change the practices complained of or help to protect individuals from further violations.

One example is the effort by human rights lawyers and advocates in the US who have engaged with Special Rapporteurs in a range of ways, including through confidential communication procedures. In 2012, the Maryland Legal Aid Bureau (MDLAB), along with a coalition of over two dozen organizations from the US, including legal services and community-based organizations, sent a communication to the UN Special Rapporteur on extreme poverty and human rights, highlighting the issue of lack of access to justice for migrant workers and their families. ${ }^{63}$ It included how law, policy, and practice result in a situation where 'outreach workers who attempt to provide farmworkers living at labor camps with legal assistance, healthcare, education, and social and other basic services and are denied access altogether or not provided meaningful access [to workers]', exacerbating marginalization and socio-economic deprivation in violation of a number of human rights protections. ${ }^{64}$ The complaint also detailed how State and federal law exclude farmworkers from an array of workplace protections, and highlighted the myriad ways that law and practice violate the CERD and the ICCPR, treaties the US has signed and ratified. ${ }^{65}$ The joint communication resulted in an allegation letter to the US, which the Special Rapporteur on extreme poverty submitted jointly with the Special Rapporteurs on the situation of human rights defenders, and on the human rights of migrants. ${ }^{66}$

The communication received media coverage ${ }^{67}$ and was also invoked during subsequent advocacy with the UN Human Rights Committee, and the UPR. ${ }^{68}$ The 2012 complaint continues to impact domestic

63 Communication from Maryland Legal Aid Bureau et al. to Magdalena Sepulveda Carmona, UN Special Rapporteur on Extreme Poverty and Human Rights, Office of the High Commissioner for Human Rights (Dec. 13, 2012), http://www.coloradofarmworkers.org/wp-content/uplo ads/2017/11/Migrant-Farmworker-Camp-Access-Human-Rights-Complaint-Dec-13-2012.pdf.

64. Ibid. at 2, 8-11.

65 Ibid. at 3, 8-11.

66 See Letter from the U.S. Permanent Mission to the United Nations and other International Organizations in Geneva to the Office of the High Commissioner for Human Rights (May 2, 2014), https://spdb.ohchr.org/hrdb/27th/USA_02.05.14_(25.2012).pdf.

67 See, e.g., Mana Rabiee, 'Workers Demand Greater Access to US Migrant Workers', VOA News (Dec. 27, 2012, 9:48 AM), https://www.voanews.com/a/aid_workers_demand_greater_access_to_ us_migrant_workers/1573107.html.

68 See, e.g., Maryland Legal Aid Bureau, Access to Justice and Healthcare for Migrant Farmworkers in the United States: A Shadow Report August 2013 Prepared for the 1ogth session of the UN 
advocacy to enhance access to services for migrant workers, and to challenge the laws that keep lawyers and service providers from reaching farmworkers. An example of the latter took place in 2017, when two MDLAB staff members attempting to conduct outreach to farmworkers were cited for trespass and ordered to leave the property. MDLAB staff brought a legal action claiming violation of their First Amendment right, and the defendants filed a motion to dismiss in Maryland District Court. ${ }^{69}$ The Opinion refers to the 2012 complaint to the UN Special Rapporteur to counter the defendants' argument that the issue of access to farms was moot once the police rescinded the no-trespass order. ${ }^{70}$ The Maryland judge further found that the facts in the UN complaint demonstrated that the issue was capable of being repeated and therefore had not been rendered moot. ${ }^{71}$ By establishing a set of credible facts, the initial communication to the UN Rapporteur has influenced ongoing international and domestic advocacy, as well as litigation.

\section{e. Forums}

Over the years, the Council has established a subsidiary Expert Mechanism and various thematic forums to provide it with subject matter expertise and offer a platform for dialogue and cooperation among civil society, States and multilateral organizations. These include the Expert Mechanism on the Rights of Indigenous People, the Forum on Minority Issues, the Social Forum, the Forum on Business and Human Rights and the Forum on Human Rights Democracy and the Rule of Law.

While each of these bodies have their own distinct mandate and rules of procedure, some opportunities for advocates to engage in these processes remain common across each of the forums and the Expert Mechanism. They all meet and report to the Council through studies, research-based advice or best practices. During these meetings, advocates can organize and attend side events, deliver statements which are recorded and made available on the UN Web TV, and arrange

Human Rights Committee (August 2013), http://tbinternet.ohchr.org/Treaties/CCPR/Shared\%20 Documents/USA/INT_CCPR_NGO_USA_15224_E.pdf.

69 See Memorandum Opinion, Rivero et al. v. Montgomery County, Md., Case No. PWG-16-1186, 259 F.Supp.3d 334, 2017 WL 1684618 (D.Md., 2017).

70 Ibid. at 9-11.

71 Ibid. 
meetings with UN officials and other stakeholders. Additionally, unlike the Council's plenary sessions, members of non-ECOSOC accredited NGOs can apply to participate. The process to apply to attend, along with applications to organize side events and deliver interventions are detailed on the Council's website.

The information below highlights particular procedures for the Expert Mechanism and each of the Council's four forums that NGOs may find insightful in developing advocacy approaches.

\section{i. Expert Mechanism on the Rights of Indigenous Peoples}

The Expert Mechanism on the Rights of Indigenous Peoples (EMRIP) provides the Council with expertise and advice on the rights of indigenous peoples, as set out in the UN Declaration on the Rights of Indigenous Peoples (UNDRIP). ${ }^{72}$ It convenes annually for five days, typically in July, at the UN Headquarters in Geneva and holds a series of public and private meetings. ${ }^{73}$ Representatives from States, indigenous peoples' organizations, civil society, inter-governmental organizations and academia may participate in its sessions. EMRIP presents its reports to the Council during the September session, in a clustered interactive dialogue with the Special Rapporteur on the Rights of Indigenous Peoples (SRRIP). ${ }^{74}$ In September 2016, the Council adopted Resolution 33/25, revising EMRIP's mandate in several significant ways. ${ }^{75}$ Most notably, the revised mandate expanded EMRIP's focus from global thematic issues to include new country-specific procedures. Such procedures may involve providing technical advice on domestic legislation, implementing recommendations arising from human rights mechanisms, and facilitating dialogue between the different stakeholders, including the private sector. ${ }^{76}$

EMRIP provides NGOs, indigenous peoples' organizations, academics and other civil society members several opportunities to help fulfill its mandate. Such opportunities include: participating at EMRIP sessions, contributing to reports, and engaging in the new country engagement

\footnotetext{
72 The Expert Mechanism on the Rights of Indigenous Peoples, OHCHR, http://www.ohchr.org/EN/ Issues/IPeoples/EMRIP/Pages/EMRIPIndex.aspx (last visited Apr. 4, 2018).

73 Ibid.

74. See Programme of Work for the 36 th Session, supra note 12.

75 Human Rights Council Res. 33/25, Revised Mandate of the Expert Mechanism on the Rights of Indigenous Peoples, 4, A/HRC/RES/33/25 (Sept. 30, 2016) [hereinafter Human Rights Council Res. 33/25].

76 Ibid., $2 \odot-(e)$.
} 
procedures. Since the ways in which advocates may participate at EMRIP sessions are generally the same across other forums, the sections below will focus on the latter two ways advocates can engage with EMRIP.

Resolution 33/25 mandates that EMRIP present three reports to the Council's September session: (1) an annual report summarizing its work throughout the year; (2) a thematic study on the status of the rights of indigenous peoples worldwide; and (3) a report on good practices and lessons learned in achieving the ends of the UNDRIP. ${ }^{77}$ The latter two reports are prepared following formal and informal consultations with a wide variety of stakeholders, including indigenous peoples, NGOs, and academics.

The Expert Mechanism decides on the subject of its thematic study by mid-June of each year, and announces the theme during its annual session in July. ${ }^{78}$ After the theme is announced, contributions are solicited through calls for submissions to a broad variety of stakeholders including States, national human rights institutions, as well as indigenous peoples, academics and other members of civil society. ${ }^{79}$ Calls for written submissions are typically circulated by November through the OHCHR website and its UN Human Rights Weekly Update list serve, with a submission deadline often set for late February. To guide contributions, EMRIP provides a concept note that offers a draft structure for of its thematic report organized largely by the relevant articles of the UNDRIP. ${ }^{80}$ All submissions to EMRIP's thematic study are made public on the OHCHR website. ${ }^{81}$ Advocates can also influence the content of thematic reports by delivering oral interventions during EMRIP's annual session where a draft of the report is presented. These statements are typically limited to five minutes, although participants should be prepared to deliver abridged versions if the Chairperson reduces the time allotted to speakers from the floor.

77 Ibid., 9 2(a)-(b) and 3 .

78 Human Rights Council, Expert Mechanism on the Rights of Indigenous Peoples, Methods of work for Reports to the Human Rights Council and Country Engagement, at 2, http://www.ohchr.org/ Documents/Issues/IPeoples/EMRIP/Session10/EMRIP_MethodsofWork.pdf (last visited Aug. $25,2018)$.

79 OHCHR's posts calls for submissions on its website. See Study on Free, Prior and Informed Consent, OHCHR, http://www.ohchr.org/EN/Issues/IPeoples/EMRIP/Pages/StudyFPIC.aspx (last visited Apr. 16, 2018).

80 Ibid.

81 Ibid. 
The revised mandate stipulates an additional requirement that EMRIP identify, disseminate and promote good practices and lessons learned regarding the efforts to achieve the ends of the UNDRIP through a separate annual report. ${ }^{82}$ To date, EMRIP has yet to submit such a report and the methods in which such information is solicited has yet to be determined.

Upon the request of Member States, indigenous peoples and even the private sector, EMRIP's new country engagement procedure can help provide technical advice regarding the development of domestic legislation and policies pertaining to indigenous peoples, assist Member States in implementing recommendations arising from UN human rights mechanisms, or facilitate dialogue between various stakeholders to advance the ends of the UNDRIP. ${ }^{83}$

While the amended EMRIP mandate provides country-specific procedures, it is limited to providing technical advice, assistance and facilitating such types of dialogue detailed above. EMRIP cannot receive or pass on complaints or denunciations; that procedure falls largely within the scope of the Special Rapporteur on the Rights of Indigenous Peoples (SRIP) and other special procedures mandate holders. ${ }^{84}$

To date, EMRIP has undertaken two country engagement missions under its revised mandate, one to support Mexico City authorities in developing laws and policies for the implementation of the rights of indigenous peoples under the Constitution and another to consider amendments to the Sámi Parliament Act in Finland. ${ }^{85}$ Other activities envisaged by EMRIP's new methods of work include increasing awareness of the Expert Mechanism mandate and promoting understanding

82 Human Rights Council Res. 19/23, UN Doc A/HRC/RES/19/23 (Mar. 23, 2012).

83 Human Rights Council, Annual Rep. of the Expert Mechanism on the Rights of Indigenous Peoples, 7 , at 21-22, UN Doc A/HRC/36/57 (Aug. 8, 2017) [hereinafter Annual Report of the Expert Mechanism 2017].

84 Indigenous Peoples' Center for Documentation, Research and Information, Fact Sheet on the Expert Mechanism on the Rights of Indigenous Peoples, at 1, https://www.docip.org/fileadmin/ user_upload/Fiche-MEDPA_en.pdf (last visited Aug. 25, 2018).

85 Mecanismo De Expertos Sobre Los Derechos De Los Pueblos Indígenas, Misión de Cooperación Técnica a la Ciudad de México [trans. Expert Mechanism on the Rights of Indigenous Peoples, Technical Cooperation Mission to Mexico City] (Feb. 28-Mar. 2, 2018) (original in Spanish), OHCHR, http://www.ohchr.org/Documents/Issues/IPeoples/EMRIP/ EMRIPTechnicalCooperationMexico.pdf; Expert Mechanism on the Rights of Indigenous Peoples, Country Engagement Mission - Finland (Feb. 16, 2018), OHCHR, http://www.ohchr. org/Documents/Issues/IPeoples/EMRIP/CountryEngagementFinlandMissionStatement.pdf. 
of the Declaration at country level, site visits and public lectures. ${ }^{86}$ A detailed overview of EMRIP's new methods of work with respect to country engagement activities, including ways in which indigenous peoples can submit requests, is set out in Annex I of its Annual Report, adopted at its tenth session in July $2017 .^{87}$

\section{ii. Forum on Minority Issues}

The Forum on Minority Issues is a two-day annual conference organized under the auspices the UN's Special Rapporteur on Minority Issues at the UN Headquarters in Geneva, typically in late November or early December. It was established through Human Rights Council Resolution 6/15 of 28 September 2007 and renewed by Resolution 19/23 of 23 March 2012 to continue the work of the Working Group on Minorities of the Sub-Commission on the Promotion and Protection of Human Rights, which operated under the Commission on Human Rights. ${ }^{88}$ The aim of the Forum is to provide a platform for promoting dialogue and cooperation on issues pertaining to minority issues as well as thematic contributions to the work of the Special Rapporteur. ${ }^{89}$ Each year, discussions at the Forum focus on a specific theme with respect to minority rights in relation to the UN Declaration on the Rights of Persons Belonging to National or Ethnic, Religious and Linguistic Minorities. ${ }^{90}$ In the past, the Forum has examined the situation of minorities and the right to political participation, sought to promote the rights of minority women and girls, and worked toward guaranteeing the rights of religious minorities. ${ }^{91}$ The Forum's Chairperson is appointed by the President of the Human Rights Council on the basis of regional rotation and in consultation with Regional Groups. ${ }^{92}$

In previous years, participation at the Forum was premised around draft recommendations prepared by the Special Rapporteur. These action-oriented recommendations outline opportunities on how States, inter-governmental organizations, civil society and others can better protect and promote the rights of minorities with respect to that year's

\footnotetext{
86 Annual Report of the Expert Mechanism 2017, supra note 83.

87 Ibid.

88 HRC Res 19/23, supra note 82.

89 Ibid. 5 .

90 Previous sessions of the Forum on Minority Issues available at http://www.ohchr.org/EN/

HRBodies/HRC/Minority/Pages/PreviousSessions.aspx (last visited Apr. 4, 2018).

91 Ibid.

92 HRC Res 19/23, supra note 82, at 9.
} 
theme. ${ }^{93}$ During the Forum, participants were invited to comment on the Special Rapporteur's draft recommendations through oral interventions that discussed positive practices and continued challenges in safeguarding minority rights in their own contexts. The Special Rapporteur later updated the draft recommendations by incorporating comments provided by participants during the Forum. The final recommendations were presented to the Human Rights Council at the subsequent session where they were formally adopted..$^{94}$ During the latest session of the Forum, the new Special Rapporteur, Dr Fernand de Varennes, invited participants to reference previous years' recommendations, the Declaration on the Rights of Persons Belonging to National or Ethnic, Religious and Linguistic Minorities Recommendations, and other documents in lieu of prepared draft recommendations. ${ }^{95}$

The Forum's programme of work is typically organized into six agenda items over the course of two days: an opening meeting, closing remarks and four panel discussions centered on topics pertaining to that year's theme. ${ }^{96}$ During the panel discussion, two to three experts from NGOs present roughly 15 -minute statements on the topic relating to the particular agenda item. The time remaining under that agenda item is dedicated to an interactive dialogue where participants can deliver two or three minute oral interventions from the floor. ${ }^{97}$ All participants, whether representatives of NGOs, States, or UN mechanisms, are allotted the same time for statements during the interactive dialogue. Nevertheless, Member States are still able to raise a point of order if statements violate the Human Rights Council's Rules of Procedures. If a point of order is raised by a State, the Chairperson decides whether the speaker is permitted to finish the rest of her statement. ${ }^{98}$ Advocates can evade having a point of order raised during their oral intervention

93 Ibid. 10.

94 HRC, 34th Session held Feb. 27-Mar. 24, 2017, Recommendations of the Forum on Minority Issues at its Ninth Session: Minorities in Situations of Humanitarian Crises, UN Doc A/ HRC/34/68 (Jan. 13, 2017).

95 HRC, 37th Session held Feb. 26-March 23, 2018, Report of the Special Rapporteur Recommendations of the Forum on Minority Issues at its Tenth Session on the Theme 'Minority Youth: Towards Inclusive and Diverse Societies,' 9 2, UN Doc A/HRC/37/73 (Jan. 30, 2018).

96 See UN Forum on Minority Issues, Programme of Work for Its 1oth Session to be held Nov. 3-Dec.1, 2017 in Geneva, http://www.ohchr.org/Documents/HRBodies/HRCouncil/MinorityIssues/Session10/pow.pdf.

97 Ibid.

98 HRC Res. 5/1, Institution-building of the United Nations Human Rights Council, $\mathbb{S}$ VII $\mathbf{1}$, UN Doc A/HRC/RES/5/1 (June 18, 2017), states that '[t]he Human Rights Council shall apply the rules of procedure established for the Main Committees of the General Assembly, as applicable, 
by discussing issues relevant to the agenda item at hand, avoiding abusive or inflammatory language, and ensuring that they refer to Member States or territories by their official names.

Participants are also able to organize side events during the lunch hour of either of the two days. Unlike sessions of the Council, registering to participate or organize a side event is not just limited to those who enjoy ECOSOC accreditation but open to other 'NGOs whose aims and purposes are in conformity with the spirit, purposes and principles of the Charter of the United Nations'. ${ }^{99}$ Details on how to register to attend the Forum and how to organize a side event are listed on the Forum on Minority Issues website. ${ }^{100}$ Registering to deliver an oral intervention was typically done in person at the Human Rights Council chamber at the start of each session. At the 1oth Session of the Forum on Minority Issues those interested were invited to speak and present relevant questions to the panelists by raising their hands from the floor. Advocates should note that given the limited time allotted to interactive dialogues, not all participants interested in delivering an intervention under a particular agenda item will be given an opportunity speak.

\section{iii. Social Forum}

The Social Forum is a unique space for interactive exchange between civil society actors, inter-governmental organizations, and representatives of Member States on a theme relating to enjoyment of economic, social and cultural rights within the context of globalization. ${ }^{101}$ Like the UN's Forum on Minority Issues, the Social Forum emerged out of the Sub-Commission on the Protection and Promotion of Human Rights, and was preserved as a subsidiary body of the Human Rights

unless subsequently otherwise decided by the Assembly or the Council'. Rule 133 of the General Assembly's Rules of Procedure, in turn, provides as follows:

\footnotetext{
During the discussion of any matter, a representative may rise to a point of order, and the point of order shall be immediately decided by the Chairman in accordance with the rules of procedure. A representative may appeal against the ruling of the Chairman. The appeal shall be immediately put to the vote, and the Chairman's ruling shall stand unless overruled by a majority of the members present and voting. A representative rising to a point of order may not speak on the substance of the matter under discussion.

GA Rules of Procedure, UN Doc A/520/Rev.17, UN Sales No. E.08.I.931 (embodying amends and additions up to Sept. 2007).

99 HRC Res 19/23, supra note 82, 96.

100 Information for all Participants, OHCHR, http://www.ohchr.org/EN/HRBodies/HRC/Minority/ Pages/InfoParticipantsSession7.aspx (last visited Apr. 4, 2018).

101 Sub-Commission on Prevention of Discrimination and Protection of Minorities Res. 2001/24, The Social Forum, 3, UN Doc E/CN.4/Sub.2/RES/2001/24 (Aug. 16, 2001).
} 
Council in 2006. ${ }^{102}$ It convenes once a year (usually in October) for three days on a theme chosen by the Human Rights Council during its June session. ${ }^{103}$ The Social Forum is unique in that it is also open to the participation of emerging actors, such as: small groups and rural and urban associations from the North and the South; anti-poverty groups; peasants' and farmers' organizations and their national and international associations; voluntary service organizations; youth associations; grassroots organizations, trade unions and associations of workers. ${ }^{104}$

One major concern in devising the Social Forum was to ensure that its work did not duplicate that of other UN bodies and mechanisms. ${ }^{105}$ According to Joe Pitts:

The consensus was that the Social Forum's unique role could be to give a voice within the U.N. to the poor and those otherwise excluded on these issues. Ideally, the Social Forum could thus contribute to democratizing global economic governance by encouraging prior consultation with and participation by those affected by crucial decisions underlying globalization. ${ }^{106}$

However barriers to accessing the Social Forum, such as the high cost of travel to UN Headquarters in Geneva where the Forum convenes, has left those the Forum intended to serve - poor and marginalized communities - from enjoying meaningful representation. In 2013, the Human Rights Council created a Special Fund for the Participation of Civil Society in the Social Forum, the Forum on Minority Issues and the Forum on Business and Human Rights to 'facilitate the broadest possible participation of civil society representatives'. ${ }^{107}$

\footnotetext{
102 HRC Res 6/13, 3 , UN Doc A/HRC/6/13 (Sept. 28, 2007) [hereinafter Social Forum].

103 Previous Sessions [of the Forum on Minority Issues], OHCHR, http://www.ohchr.org/EN/ HRBodies/HRC/Minority/Pages/PreviousSessions.aspx (last visited Apr. 4, 2018).

104 OHCHR, A Practical Guide for Civil Society, The Social Forum of the Human Rights Council, at p.5, http://www.ohchr.org/Documents/Issues/SForum/SForum2012/Guide_Social_Forum_ EN.pdf (last visited Aug. 26, 2018).

105 David Weissbrodt, et al., 'A Review of the Fifty-third Session of the United Nations SubCommission on the Promotion and Protection of Human Rights', 2o Neth. Q. Hum. Rts. 231, 242 (2002).

106 Joe W. III Pitts, 'The First U.N. Social Forum: History and Analysis', 31 Denv. J. Int'l L. \& Pol'y, 297, 300 (2002).

107 HRC Dec. 24/118, Establishment of a special fund for the participation of civil society in the Social Forum, the Forum on Minority Issues and the Forum on Business and Human Rights, $\mathbf{g}$, UN Doc A/24/118 (Oct. 4, 2013).
} 
Since 2008, the Social Forum has focused on the following themes: ${ }^{108}$

- eradication of poverty and social dimension of the globalization process (2008)

- impacts of economic and financial crises on efforts to combat poverty (2009)

- adverse effects of climate change on human rights (2010)

- promotion of the right to development (2011)

- people-centered development and globalization (2012)

- the rights of older persons (2014)

- access to medicines in the context of the right to health (2015)

- human rights and fundamental freedoms of persons with disabilities (2016)

- the promotion and protection of human rights in the context of the human immunodeficiency virus (HIV) epidemic and other communicable diseases and epidemics (2017).

The Social Forum is guided by a Chairperson appointed by the President of the Human Rights Council on the basis of regional rotation and in consultation with Regional Groups. ${ }^{109}$ The three-day forum is typically divided into morning and afternoon meetings with a series of panel discussions with experts and breakout meetings pertaining to subjects relating to that year's theme. ${ }^{110}$ Participants are invited to contribute to the discussions through interactive dialogues with the panelists. Typically, the speakers' list will open for all of the sessions at 9:30 am each day. Sign up is on a first-come, first-served basis and all interventions are limited to two minutes. Due to time limitations, the opportunity to speak cannot be guaranteed and the list for each session

\footnotetext{
108 See, The Social Forum of the Human Rights Council, OHCHR, http://www.ohchr.org/EN/ Issues/Poverty/SForum/Pages/SForumIndex.aspx (last visited Apr. 4, 2018).

109 Social Forum, supra note 102, 6.

110 See HRC, Programme of Work for the Social Forum (Oct. 2-4, 2017), OHCHR, http://www. ohchr.org/Documents/Issues/Poverty/2017SF/PoW.docx (last visited Apr. 4, 2018).
} 
will not be carried over to the next session. Speakers should be present and ready to intervene when they are called. ${ }^{111}$ The outcome of the Social Forum is a report by the Chairperson containing a summary of the discussions, conclusions, and recommendations from the Forum. The report is presented to the Council and adopted during its March session while the theme of the subsequent Social Forum is decided in a resolution introduced during the Council's June meeting. ${ }^{112}$

In practice, the Forum has been characterized as 'divisive' and 'viewed as marginal by States, subsequently attracting low participation.' Many of its conclusions and recommendations touch on 'third generation' issues such as climate change, development and economic crisis, which have not enjoyed wide acceptance among Council members. ${ }^{113}$

\section{iv. Forum on Business and Human Rights}

Pursuant to resolutions of the Council establishing the UN Forum on Business and Human Rights it is chaired by the Working Group on Business and Human Rights, one of the special procedures of the Council. ${ }^{114}$ The Forum was set up as part of the resolution that endorsed the Guiding Principles on Business and Human Rights. ${ }^{115}$ The goal of the Forum is to move the guiding principles from paper to practice.

Since December 2012, this Forum has met for three days at the end of November or beginning of December. The Forum has addressed topics that relate to the guiding principles framework of protect, respect and remedy, and current issues related to business and human rights. The Council established the Forum to serve as the global platform

111 See Speaking at the 2015 Social Forum, The 2015 Social Forum, OHCHR, http://www.ohchr.org/ EN/Issues/Poverty/SForum/Pages/SForum2015.aspx (last visited Apr. 4, 2018).

112 See Rep. of the Co-Chair Rapporteurs, 2017 Social Forum, held during the 37th Session of the Human Rights Council, Feb. 26-Mar. 23, 2018, UN Doc No A/HRC/37/74 (advance unedited version) (Feb. 2, 2018); See also, HRC Res. 35/28, The Social Forum, UN Doc A/35/28 (June 23, 2017).

113 Lucy Richardson, 'Economic, Social and Cultural Rights (and Beyond) in the UN Human Rights Council', 15 Hum. Rts. L. Rev. 409, 409-40 (2015).

114 See e.g., HRC Res. 17/4, Human rights and transnational corporations and other business enterprises, UN Doc A/HRC/RES/17/4 (July 6, 2011); see also, Human Rights Council Res. 35/7, Business and human rights: mandate of the Working Group on the issue of human rights and transnational corporations and other business enterprises, UN Doc A/HRC/RES/35/7 (July 14, 2017).

115 HRC Res. 17/4, supra note 114, 12 (The Guiding Principles on Business and Human Rights are available at www.ohchr.org/Documents/Publications/GuidingPrinciplesBusinessHR/EN/pdf). 
for stakeholders to discuss the trends and challenges in implementing the guiding principles. Both accredited and non-accredited NGOs can participate in the Forum both by participating in the panels at the Forum as well as attending the meetings. Each Spring before the Forum, the OHCHR sends out notices asking for proposals for panels at the Forum. The deadline for the proposals is in June. Side events at the Forum itself are not permitted, but the OHCHR encourages civil society to plan events at other venues during the Forum. ${ }^{116}$ A report is prepared at the end of the Forum and submitted to the Council session the following year. ${ }^{117}$

\section{v. Forum on Human Rights, Democracy and the Rule of Law}

In March 2012, during its 19th regular session, the Human Rights Council considered a resolution reaffirming that democracy is vital for the promotion and protection of all human rights, and decided to organize a panel discussion on 'common challenges facing States in their efforts to secure democracy and the rule of law from a human rights perspective'. ${ }^{118}$ In 2013, the panel discussion concluded with recommendations for an international forum to elaborate a framework for education, democracy and human rights. ${ }^{119}$ The creation of the Forum on Human Rights, Democracy and the Rule of Law was adopted by a vote of the Human Rights Council in 2015. The resolution passed, but faced abstentions from 11 countries including the Russian Federation, China and South Africa. ${ }^{120}$

The latest of the UN Human Rights Council Forums, the Forum on Human Rights, Democracy and the Rule of Law is structured similar to other periodic, multi-stakeholder UN meetings. It is mandated to convene for two days around a particular theme and its Chairperson is selected by the President of the Council on a basis of regional rotation with consultation from Regional Groups. It aims to promote dialogue and cooperation by engaging with a variety of stakeholders, including

\footnotetext{
116 For information on the page for the 2018 Forum see https://www.ohchr.org/EN/Issues/Busi ness/Forum/Pages/2018ForumBHR.aspx.

117 HRC, Report of the Working Group on the issue of human rights and transnational corporations and other business enterprises on the sixth session of the Forum on Business and Human Rights, UN Doc A/HRC/38/49 (Apr. 23, 2018).

118 HRC Res 19/36, 26, UN Doc A/19/36 (Mar. 23, 2012).

$119 \mathrm{OHCHR}$, Outcome of the panel discussion on common challenges facing States in their efforts to secure democracy and the rule of law from a human rights perspective, 23 , UN Doc A/ HRC/24/54 (Aug. 6, 2013).

120 HRC Res 28/14, UN Doc A/28/14 (Mar. 26, 2015).
} 
NGOs. ${ }^{121}$ Unlike other Forums, however, the Forum on Human Rights, Democracy and the Rule of Law only convenes every two years. In addition to oral interventions from the floor, stakeholders can submit written input in advance of the session on suggestions to the Forum's programme of work. ${ }^{122}$ Calls for written submissions are circulated six months before the Forum meets and are made public on the UN website. ${ }^{123}$ Its discussions and recommendations are presented in a report during the subsequent March meeting of the Council and the theme of the next Forum session is determined by resolution during its June session. ${ }^{124}$ Since the Special Fund for the Participation of Civil Society was created in 2013 before the Forum on Human Rights, Democracy and the Rule of Law was created, the OHCHR offers little financial assistance for civil society organizations wishing to participate. ${ }^{125}$ Nonetheless, the inaugural Forum on Human Rights, Democracy and the Rule of Law garnered over 600 participants, including representatives from civil society, the private sector, academics, UN officials and UN Member States. ${ }^{126}$

\section{f. The Advisory Committee}

In 2006, the Advisory Committee replaced the Sub-Commission on Promotion and Protection of Human Rights, the expert body of the Commission on Human Rights. However, the Advisory Committee has 18 members rather than the 26 which comprised the Sub-Commission. Like the Sub-Commission, the members are individuals acting in their personal capacity instead of governments but are still representative of the various regions of the world: five each from Africa and Asia; two from Eastern Europe; and three each from GRULAC (Grupo Latinamericano) and WEOG (Western Europe and Others). The Advisory Committee meets for one week twice a year - in January/

\footnotetext{
121 Ibid., g9 3-7.

122 Ibid., 4.

123 See OHCHR, UN Forum on Human Rights, Democracy and the Rule of Law 2018, https://www. ohchr.org/EN/HRBodies/HRC/Democracy/Pages/ForumDemocracy.aspx (last visited July 10, 2018).

124 See Rep. of the Co-Chair Rapporteurs, 2017 Social Forum, held during the 37th Session of the Human Rights Council, Feb. 26-Mar. 23, 2018, UN Doc No. A/HRC/37/74 (advance unedited version) (Feb. 2, 2018) (Social Forum report adopted at HRC); see also HRC Res 35/28, UN Doc $\mathrm{A} / 35 / 28$ (June 23, 2017) (Resolution adopting next Forum's theme).

125 HRC Dec. 24/118, supra note 107.

126 OHCHR, Final List of Participants, https://www.ohchr.org/Documents/Issues/Democracy/ Forum2016/Final_list_participants.pdf (last visited July 10, 2018).
} 
February and August. ${ }^{127}$ Delegates from both governments and NGOs are allowed to participate in the meetings. NGOs with ECOSOC accreditation (see below) are allowed to attend all the meetings. The Advisory Committee posts its process for registering NGOs without ECOSOC accreditation around a month before its sessions.

The Sub-Commission used to take a great deal of initiative in addressing topics that were not addressed in other venues. It undertook ground-breaking studies on issues like the right to adequate housing, the right to food, the rights of non-citizens, the right to a fair trial, and states of emergency. It drafted the Norms on the Responsibilities of Transnational Corporations and Other Business Enterprises with Regard to Human Rights, which while not approved by the Commission on Human Rights were the spark that resulted in the work at the Human Rights Council on corporate accountability. The Sub-Commission also addressed human rights violations by governments until 2000 when the Commission on Human Rights limited the Sub-Commission's ability to adopt country specific resolutions and emphasized that it was an independent advisory body of the Commission.

These restrictions were passed on to the Advisory Committee. So now the main country-related work is through the Working Group on Communications that address the 1503 procedure. Nonetheless, because it is made up of experts, NGOs might find it easier to meet with the delegates and raise innovative issues for it to consider.

\section{g. The Council's communications/complaint procedure}

In 1970, ECOSOC adopted Resolution 1503, which allowed NGOs to submit complaints regarding 'situations which appear to reveal a consistent pattern of gross and reliably attested violations of human rights'. ${ }^{128}$ These communications were initially addressed by the SubCommission on Promotion and Protection of Human Rights which developed admissibility requirements which are still being used

127 For the Reports of the Advisory Committee's meetings in August 2017 and February 2018 see HRC, Report of the Advisory Committee on its nineteenth session, UN Doc A/HRC/AC/19/2 (Sep. 18, 2017); HRC, Report of the Advisory Committee on its twentieth session, UN Doc A/ HRC/AC/20/2 (Mar. 29, 2018).

128 Economic and Social Council Res. 1503 (XLVIII), 48 UN ESCOR (No. 1A), UN Doc E/4832/ Add.1, at 8 (1970). 
today by the Human Rights Council and the Working Group on Communications that reports to it. These requirements are that:

- 'there are reasonable grounds to believe that they may reveal a consistent pattern of gross and reliably attested violations of human rights and fundamental freedoms, including policies of racial discrimination and segregation and of apartheid in any country...'

- the communication is not anonymous (though the authors can request that their names not be revealed to the government);

- the facts must indicate what rights have been violated;

- second-hand information may be included as long as there is also clear evidence;

- abusive language, insulting references to the State involved, or complaints that have 'manifestly political motivations' are not permitted;

- the communications cannot be 'based exclusively on reports disseminated by mass media';

- domestic remedies must be exhausted as long as they exist and are not 'ineffective or unreasonably prolonged'; and

- the communication is submitted within 'a reasonable time after the exhaustion of domestic remedies'. ${ }^{129}$

In order to give the concerned government 12 weeks to respond to the complaint before the Working Group on Communications (WG) meets in March/April and October, the complaints must be submitted in late January and July. Because the WG receives 20,000-25,000 communications each year, they need to be comprehensive but brief - in the range of $10-20$ pages. They should include information about the overall situation in a country, refer to the serious human rights violations including their frequency, and provide details of several individual cases. The WG has authority to consolidate individual

129 Sub-Commission on Prevention of Discrimination and Protection of Minorities, Resolution 1 (XXIV), UN Doc E/CN.4/1070, at pp.50-51 (1971), http://www1.umn.edu/humanrts/demo /1503Resolution1.html [hereinafter Sub-Comm'n Res. 1]. 
communications but rarely does, so it is important that each communication can support a finding that a government is responsible for a consistent pattern of gross and reliably attested violations. An appendix can be attached to the communication to include more detail, but while the staff will translate the principal text of the communication it will not translate the appendix.

Over the course of the evolution of the 1503 procedure under the Commission on Human Rights, changes were made regarding the screening process by the Commission and the Sub-Commission on the Promotion and Protection of Human Rights. ${ }^{130}$ One crucial development took place in 1978 when the Chair of the Commission announced the names of governments being considered under the procedure. ${ }^{131}$ In 1984, the Commission's Chair announced not only the names of the countries that were discussed under the procedure, but also which countries the Commission had decided to keep under consideration. ${ }^{132}$ This at least gave advocates information regarding the complaints they had filed.

Because the 1503 procedure is confidential, it is difficult to assess the effectiveness of filing complaints under the procedure. However, a list of cases handled by the Commission on Human Rights has been released and the decisions are now listed as 'Derestricted' but access to them is still not available. Under the guidelines regarding the availability of confidential cases listed as 'Derestricted' or DER should be available, ${ }^{133}$ but this is not the case except for situations where the Commission and subsequently the Council have decided to make the case files public. This happened in various contexts, including a change of government in the country involved resulting in the new government requesting the records, and the Commission or Council deciding to make the complaint public because of lack of cooperation by the government involved. Examples of the first took place in 1985 and 1986 when new governments in Argentina, the Philippines and Uruguay requested that the records of the proceedings be made public. ${ }^{134}$ In 2003, the Commission decided to make public the 'Report

\footnotetext{
130 For an overview of the various changes in this procedure see, David Weissbrodt et al, International Human Rights: Law, Policy and Process (LexisNexis, 4th ed. 2009) (1996), p.335.

131 Ibid.

132 Ibid.

133 See, Guidelines for Specific Types of UN documents and publications, http://www.un.org/depts/ dhl/unbisref_manual/undocs/lessanalysis.html\#confidential, (last visited Aug. 25, 2018).

134 Pitts, supra note 106, at p.336.
} 
of the independent expert of the Commission on Human Rights on the situation of human rights in Liberia submitted under the 1503 procedure' 'to encourage assistance to the Government and the people of Liberia in restoring full respect for human rights and fundamental freedoms. ${ }^{135}$ However, as before there was no reference to the actual 1503 Procedure.

An example of the second one is the case against Eritrea, which resulted in having the case handed to the Special Procedures. ${ }^{136}$ It is now on the agenda under the public procedure.

Because of the confidential nature of the procedure, it is difficult for advocates to discover what the Human Rights Council is doing with respect to the complaints brought before it. While the Council can use the threat of going public with the case, it is difficult for even those who bring the complaint to see what steps either the Council or the country in question have taken.

\section{h. Special sessions}

Outside its regular sessions, the Council may convene special sessions to address emerging human rights crises at the request of at least one-third of its membership (i.e., 16 members). ${ }^{137}$ The Council has convened 28 special sessions to date, the vast majority focusing on country-specific situations. ${ }^{138}$ Two have tackled thematic concerns, namely, the negative impact of the worsening of the world food in 2008 and the impact of the global economic and financial crises in 2009. ${ }^{139}$

In preparation for a special session, the President of the Council convenes an open-ended informative consultation a few days earlier to establish its conduct and organization. ${ }^{140}$ The special session then con-

\footnotetext{
135 UN Comm'n on Human Rights, Report of the independent expert of the Commission on Human Rights on the Situation of Human Rights in Liberia Submitted Under the 1503 Procedure, UN Doc E/CN.4/2004/8, at 1 (Sep. 25, 2003).

136 Situation of Human Rights in Eritrea, Human Rights Council Res. 21/1, 2, UN Doc A/HRC/ RES/21/1 (Oct. 9, 2012).

137 HRC Res. 5/1, UN Doc A/RES/5/1, at 18, Rule 6 (June 18, 2007).

138 Human Rights Council, Special Sessions of the Human Rights Council, https://www.ohchr.org/

EN/HRBodies/HRC/SpecialSessions/Pages/SpecialSessions.aspx (last visited Jul. 7, 2018).

139 Ibid.

140 HRC Res. 5/1, supra note 137, 124.
} 
venes for a single day with a morning and afternoon meeting. ${ }^{141}$ Often officials from the OHCHR or the Secretary-General, the President of the Council, relevant special procedure mandate holders, along with the State Party concerned deliver opening statements. ${ }^{142}$ The floor is then open to a debate on a draft resolution concerning the human rights crisis at hand. ${ }^{143}$ State Members of the Council are typically given three minutes for oral interventions while non-Council Member States, UN officials and NGOs are granted two minutes. ${ }^{144}$ NGOs may also influence the debate by submitting written statements in advance of the special session. ${ }^{145}$ This procedure may be particularly helpful to advocates working on the human rights issue concerned but unable to attend the special session in person.

The resolution coming out of the special session is typically resultsoriented, often establishing a new mandate to monitor the situation or directing the OHCHR to provide technical support to the country concerned. ${ }^{146}$ In 2014, the Council convened a special session after the Iraqi city of Mosul fell to the so-called Islamic State. ${ }^{147}$ The resolution adopted at the session requests the OHCHR provide technical and human rights capacity-building assistance to the Iraqi Government and to investigate alleged violations of international human rights law. ${ }^{148}$ Earlier that year, the Council convened a special session to address the conflict in the Occupied Palestinian Territory, and established a Commission of Inquiry to investigate possible violations of international humanitarian and human rights law since June 2014 'with a view to avoiding and ending impunity and ensuring those responsible are held accountable'. ${ }^{149}$

Registration to attend special sessions, deliver interventions and submit written statements are made online through the UN's website.

\footnotetext{
141 See Rep. of the Human Rights Council on its Twenty-Seventh Special Session, 6, UN Doc A/ $\mathrm{HRC} / \mathrm{S}-27 / 3$, at 8 (Feb. 1, 2018).

142 Ibid. is 15-19.

143 HRC, Rep of the Human Rights Council on its Twenty-Second Special Session, g 17-23, UN Doc A/HRC/S-22/4 (Oct. 31, 2014) [hereinafter Rep. of H.R.C. 22nd Session].

144 Ibid. 13.

145 Economic and Social Council Res. 1996/31, g 36, 37(e), UN Doc E/RES/1996/31 (July 25, 1995). 146 HRC Res 5/1, supra note 137, 128.

147 Rep. of HRC 22nd Session, supra note 143.

148 HRC Res S-22/1, 9-10, UN Doc A/S-22/1 (Sep. 3, 2014).

149 HRC Res S-21/1, 13, UN Doc A/S-21/1 (July 24, 2014).
} 
Like regular sessions of the Council, participation by NGOs is limited to those who enjoy Consultative Status with ECOSOC. ${ }^{150}$

Advocates should note that the Council may decide - through an action initiated by a Member State or group of States - to organize urgent debates to address an emerging human rights crisis during its regular session. According to a resource guide compiled by the Permanent Mission of Switzerland to the UN in Geneva, '[u]rgent debates in some way resemble mini special sessions that are tacked on to a regular session. In practice, they deal with 'modifications to the programme of work'. ${ }^{151}$ Their format is the same as General Debates, though participants should register to deliver oral interventions in person at the Council rather than through the UN's website. $^{152}$

\section{i. $\quad$ Treaty drafting}

NGOs can play a role in both encouraging the drafting of treaties as well as participate in the drafting sessions. Treaties can be drafted by a number of bodies. The Sub-Commission on Promotion and Protection of Human Rights, discussed above, undertook the drafting of a number of treaties which were then considered and adopted by higher UN bodies. This function was taken over by the Advisory Committee that replaced the Sub-Commission in 2006. Other bodies have been involved in drafting treaties. As discussed below, one example is the Commission on the Status of Women which drafted the Optional Protocol to the Convention on the Elimination of All Forms of Discrimination Against Women. ${ }^{153}$ More recently, some members of the Council have taken initiatives to draft treaties through Working Groups approved by the Council. One example is the Working Group drafting a treaty on business and human rights. ${ }^{154}$ The Working Group

\footnotetext{
150 HRC Res. 5/1, supra note $137,125$.

151 Permanent Mission of Switzerland to the UN Office, The Human Rights Council: A Practical Guide,10 (2015), https://www.eda.admin.ch/dam/eda/en/documents/publications/Internation aleOrganisationen/Uno/Human-rights-Council-practical-guide_en.

152 Ibid.

153 GA Res. 54/4, annex, 54 UN GAOR Supp. (No. 49), at 5, UN Doc A/54/49 (Vol. 1) (20oo) (entered into force Dec. 22, 2000).

154. See HRC Res. 26/9, UN Doc A/RES/26/9 (July 14, 2014); for more information on the drafting of the treaty, see, Connie de la Vega, 'International Standards on Business and Human Rights: Is Drafting a New Treaty Worth It?', 51 USF L. Rev. 431 (2017).
} 
spent two years discussing whether to draft a treaty and in its final report to the Council it proposed that it do so. ${ }^{155}$

NGOs can be involved in the process of urging the various bodies to undertake the drafting of a treaty. Once that process is approved, they can be involved in making recommendations for topics to be covered by the treaty as well as language for its provisions. The various bodies usually request input at both stages and provide a process for making submissions in writing. NGOs should bear in mind that treaties drafted by the Advisory Committee have to be approved by the Council. Treaties approved by the Council are submitted to the GA for its approval. It is important to make sure that the proponents of the treaty have enough support to get approval of the majority of the countries at the GA. While it is difficult for NGOs to participate at that body, they can contact delegations to urge their support.

Once the GA approves a treaty, it can be opened for signature by States. Once the requisite number of States become parties it takes effect. At that point the mechanism for overseeing the treaty also goes into effect and it can be enforced under the State Parties' internal enforcement mechanisms. NGOs can be involved in both the treaties' oversight bodies as discussed below and at the national level.

The GA itself can take steps to promote treaty drafting. One example is its role in the on-going consideration of whether to draft a treaty on the rights of older persons. In 2010, it helped to establish the UN Open Ended Working Group on Ageing (OEWGA) to assess the existing international framework of the human rights of older persons. ${ }^{156}$ In 2012, the GA requested that OEWGA consider proposals for a new instrument on that topic. ${ }^{157}$ There has been a great deal of debate on whether a treaty is needed. ${ }^{158}$ Despite the debate, OEWGA continues to meet to discuss gaps in protection of seniors' rights. ${ }^{159}$

\footnotetext{
155 HRC Report of the Working Group on the issue of human rights and transnational corporations and other business enterprises on the sixth session of the Forum on Business and Human Rights, UN Doc A/HRC/38/49 (Apr. 23, 2018).

156 GA Res 65/182, Follow-up to the 2nd World Assembly on Ageing, 28 (Dec. 21, 2010).

157 GA Res 67/139, Towards a comprehensive and integral international legal instrument to promote and protect the rights and dignity of older persons, 1 (Dec. 20, 2012).

158 See Marijke de Pauw, Berkeley Journal of International Law Blog (May 4, 2015), www.berkeleytravaux.com/toward-new-un-convention-rights-older-persons/.

159 Léon Poffé, 'Towards a New United Nations Convention for Older Persons', 15 Hum. Rts. L. Rev. 591, 599-601 (2015).
} 


\section{j. World conferences}

The first UN World Conference on Women was held in Mexico City in 1975 and addressed the rights of women in the Declaration on the Equality of Women and their Contribution to Development and Peace. It followed from the International Women's Day held the year before. Follow-up conferences were held in Copenhagen (1980), Nairobi (1985), and Beijing (1995), where the Declaration and Platform of Action were adopted. These were aimed at achieving greater equality and opportunity for women. The first conference to address human rights was the World Conference on Human Rights held in Vienna, Austria in 1993. The Vienna Declaration and Programme of Action were adopted which were an important contribution to universal protection and promotion of human rights.

The outcome documents of world conferences are voted on by country delegates. However, a large role at the conferences is played by civil society and NGOs. Each conference has a separate process for signing up for participation and membership in ECOSOC accredited NGOs is not required.

\section{k. Fact investigation procedures}

There are a number of mechanisms that the Council makes use of for purposes of fact-finding. These include FFMs and COIs. These procedures are also used by other bodies of the UN, including the Security Council, the GA as well as the Secretary-General and the High Commissioner for Human Rights. They are used to respond to serious violations of international humanitarian and human rights law in either sudden or protracted situations. ${ }^{160}$ The purpose of these is generally to promote accountability and to counter impunity. The OHCHR has published a guide book with extensive information regarding these fact-finding mechanisms. ${ }^{161}$ There is no formal process for NGOs to contribute to the work of the COIs. Nevertheless they can influence reports by meeting with $\mathrm{COI}$ members and sharing developments on the ground.

160 Commissions of Inquiry, Fact-Finding Missions and other Investigations, OHCHR, http://www. ohchr.org/EN/HRBodies/HRC/Pages/COIs.aspx (last visited Nov. 7, 2017).

161 Commissions of Inquiry and Fact-Finding Missions on International Human Rights and Humanitarian Law: Guidance and Practice, OHCHR, http://www.ohchr.org/EN/HRBodies/ HRC/Pages/COIs.aspx (last visited Nov. 7 2017). 
A recent report has assessed the use of COIs by the Council and concludes that their reports are 'relatively strong outcomes on moral accountability but weak on political and legal accountability measures'. ${ }^{162}$ In general, the COIs address three concerns: they are made by independent fact-finders; they include punitive or corrective action to both remedy and deter future abuses; and they can identify State and non-State perpetrators to mobilize political pressure for pursuing justice, institutional reform, and capacity building. ${ }^{163}$ The author goes on to discuss whether the COIs should release names of perpetrators since that can have mixed results. While it could help prosecutors initiate cases, it can also raise claims of bias and due process since the methodologies used in preparing reports are not designed for collecting evidence that can be used in court. ${ }^{164} \mathrm{He}$ also questions whether releasing names helps or harms a resolution of the conflict. ${ }^{165}$ While no COI report has resulted in either a domestic or international trial, they can play a role in encouraging national or international investigations. ${ }^{166} \mathrm{He}$ uses the example of the DPRK of how the initial COI conclusion that the government was responsible for crimes against humanity led to the government engaging with the UN human rights mechanisms, including the UPR. However, when the GA referred the report's findings to the Security Council the DPRK refused cooperation with any other UN mechanism, including the UPR. ${ }^{167}$ The report encouraged the US Congress to adopt sanctions against the DPRK and then President Obama to call for sanctions against specific individuals for human rights violations. ${ }^{168}$

Thus, fact-finding is a critical function for victims and a first step for the pursuit of other types of accountability, and can lay groundwork for policy measures and institutional reforms to prevent future violations and combat impunity. NGOs preparing reports need to bear in mind that the preliminary fact-finding is only the first step for ultimately getting redress for victims. It needs to be part of a larger advocacy plan

\footnotetext{
162 Ted Piccone, U..Human Rights Commissions of Inquiry: The Quest for Accountability (Brookings Institute Foreign Policy Program 14 (Dec. 2017), https://www.brookings.edu/wpcontent/uploads/2017/12/fp_20171208_un_human_rights_commisions_inquiry.pdf.

163 Ibid. at p.2.

164 Ibid. at p.6.

165 Ibid. at p.10.

166 Ibid. at p.5.

167 Ibid. at p.11.

168 Ibid. at p.13.
} 
to lay the groundwork for policy measures and institutional reforms to prevent future violations and combat impunity. ${ }^{169}$

The Human Rights Council had only two COIs in 2017 - on Syria and Burundi. In the recent past, there were COIs on Eritrea and the DPRK. The COI on Syria offers an example of how the procedure has been used. The most recent resolution on Syria reviews the background on this procedure going back to when the COI was approved by the Human Rights Council in 2011:

Welcomes the work of the Independent International Commission of Inquiry on the Syrian Arab Republic, established by the Human Rights Council in its resolution S-17/1 of 23 August 2011, to investigate all alleged violations and abuses of international human rights law since March 2011 in the Syrian Arab Republic, to establish the facts and circumstances and to support efforts to ensure that perpetrators of abuses and violations, including those who may be responsible for crimes against humanity, are held accountable, and notes the importance of the work of the Commission of Inquiry and the information it has collected in support of future accountability efforts, in particular the information on those who have allegedly violated international law....170

The Human Rights Council also decided to hold high level talks regarding the rights of the children in the Syrian Arab Republic and to report back at the 38 th session in 2018. ${ }^{171}$

\section{Economic and Social Council}

The Economic and Social Council (ECOSOC) is an intergovernmental body that acts under the authority of the GA, which elects its 54 members. It was the body that passed the first resolutions for addressing human rights situations by the UN, including the original Resolution 1503 complaint procedure discussed above. ECOSOC meets for one six-week session each year in New York. ${ }^{172}$ It accredits NGOs

\footnotetext{
169 Ibid. at p.14.

170 HRC Res 36/20, The Human Rights Situation in the Syrian Arab Republic, 2, UN Doc A/HRC/ RES/36/20 (Oct. 9, 2017).

171 Ibid.

172 Rule 5 of Procedure of the ECOSOC provided that 'Sessions shall be held at the Headquarters of the United Nations unless, in pursuance of a previous decision of the Council or at the request of a majority of its members, another place is designated for the whole or part of a session,' see Econ. and Social Council, Rules of Procedure of the Economic and Social Council, at 3,
} 
for participation in the UN bodies that require it. ECOSOC oversees the Commission on the Status of Women (CSW), the Commission on Crime Prevention and Criminal Justice, the Permanent Forum on Indigenous Rights and the specialized agencies of the UN. It also monitors compliance with the Covenant on Economic, Social and Cultural Rights through the Committee on Economic, Social and Cultural Rights and oversees the other human rights treaty bodies. It has issued a number of human rights standards, including the Standard Minimum Rules for the Treatment of Prisoners. ${ }^{173}$ This section will provide examples of how NGOs can participate in some of these bodies as well as the accreditation procedure.

\section{a. The Commission on the Status of Women}

The CSW was created by ECOSOC in 1946. It consists of 45 government members elected on a regional basis by ECOSOC. It meets for two weeks a year, usually in March, and rotates agenda items. The latter is useful for addressing problems that require immediate attention but the process makes it difficult to follow-up on issues since it only reviews topics every five years. It prepares reports and adopts Agreed Conclusions which comprise recommendations to ECOSOC on women's issues as well as some resolutions. It has served as a preparatory body for the UN world conferences on women. In 2005 it drafted the Optional Protocol to the Convention on the Elimination of Discrimination Against Women that set up an individual petition mechanism which it reviews. ${ }^{174}$ It also oversees the Communications Procedure that is similar to the 1503 procedure of the Human Rights Council.

The CSW Communications Procedure may be used by individuals or groups to address discriminatory practices against women in any country of the world. It addresses claims at its March session and claims need to be submitted by August 1 the year prior to the session. The CSW does not make decisions on the merits of the communications it receives so it is not useful as a source of redress for individual

E/5715/Rev.2, UN Sales No. E.92.I.22 (1992). Occasionally, substantive sessions have been held in Geneva.

173 Standard Minimum Rules for the Treatment of Prisoners, adopted Aug 30, 1955, by the First UN Congress on the Prevention of Crime and the Treatment of Offenders, UN Doc A/CONF/611, annex I, ESC res. 663C, 24 UN ESCOR Supp. (no. 1), UN Doc E/5988 (1977).

174 Sub-Comm'n Res. 1, supra note 129. 
complaints. The CSW considers the communications for purposes of identifying discriminatory practices against women and uses this process for developing policies and strategies for the promotion of gender equality. It will consider economic, social and cultural rights as well as civil and political.

Its website lists what should be included in the communications:

- identity of the women victims;

- the country where the pattern of violations have occurred;

- dates and circumstances when available;

- explain the context by providing background information;

- copies of documentation when available. ${ }^{175}$

The CSW is not as open to direct participation by NGOs as the Human Rights Council. For example, for years NGOs were not allowed to attend the drafting meetings for the Agreed Conclusions and resolutions. In the past few years some of the drafting sessions have been open so that NGOs can observe the deliberations but are still not allowed to speak publicly at the drafting sessions.

NGOs are given space to speak at the main meetings of the CSW. There is a process for signing up on the website before the meetings. When signing up, NGOs submit a summary of what their oral statement would cover. The speakers are then selected to make statements at either the main session or at side events. It is unclear what criteria are used to select the speakers, but there is an attempt to allow statements from NGOs from the various regions of the world. The chances to deliver a statement are higher if there are co-sponsors to that statement.

NGOs are usually encouraged to participate in events organized by UN Women (the UN Entity for Gender Equality and the Empowerment of Women), which was created in 2010 by the GA. ${ }^{176}$ It was built on

\footnotetext{
175 UN Women, Communication Procedure, http://www.unwomen.org/csw/communicationsprocedure.

176 For information on UN Women see www.unwomen.org.
} 
the work of the Division for the Advancement of Women (DAW), the International Research and Training Institute for the Advancement of Women (INSTRAW), the Office of the Special Adviser on Gender Issues and Advancement of Women (OSAGI), and the UN Development Fund for Women (UNIFEM). While DAW had slowly become more open to participation by civil society, NGOs had not participated as much in the other agencies and when they all merged it became more difficult for NGOs attending the CSW meetings to participate as directly as they had in DAW, and thus at the CSW. However, UN Women did release the draft Agreed Conclusions in February 2018 before the CSW62 met in March and compiled recommendations from NGOs that had submitted comments. It is difficult to say what effect this compilation had on the Agreed Conclusions adopted by the CSW and advocates still need to talk to delegates directly about their proposals.

Because the CSW only meets for two weeks each year, usually in March in New York, it often has over 5000 NGO delegates attending its meetings. This number of participants can easily overwhelm the 45 CSW delegates so NGOs are encouraged to participate in side events and their direct participation in the main meetings of the CSW is difficult. NGOs can be very involved in organizing side events on a broad number of topics at the CSW. It is a good place for meeting activists from around the world concerned with women's issues.

Because of the sheer number of participants, NGOs thus have to take opportunities in informal settings to talk to delegates regarding their suggestions for language in the Agreed Conclusions or the few resolutions adopted by the CSW. Delegates from some Member States may not be supportive of NGO participation in certain procedures or on certain issues and may devise opportunities to distract from their engagement. This may also be the case in other bodies such as the Human Rights Council, and as a result, advocates should stay mindful of their goals for participating and work towards influencing the relevant outcome documents.

\section{b. Permanent Forum on Indigenous Rights}

The Permanent Forum on Indigenous Issues (Permanent Forum) - along with EMRIP and the Special Rapporteur on the Rights of Indigenous Peoples - is one of three mechanisms at the UN mandated to address issues impacting indigenous peoples. While the 
Expert Mechanism and the Special Rapporteur report directly to the Council, the Permanent Forum advises ECOSOC across six thematic areas: economic and social development; culture; environment; education; health; and human rights. ${ }^{177}$ Its mandate is to: (1) provide expert recommendations on indigenous issues to the UN system through ECOSOC; (2) raise awareness and promote the integration and coordination of relevant activities within the UN system; and (3) prepare and disseminate information on indigenous issues. ${ }^{178}$

The Permanent Forum convenes each year, typically in May, at the UN Headquarters in New York. ${ }^{179}$ Its sessions last ten working days, and focus on a particular theme decided on at its previous session. ${ }^{180}$ Advocates can engage the Permanent Forum through oral interventions, written statements, and by organizing side events during its annual session. Given that its sessions convene some 1200 people from around the world, the Permanent Forum also serves as a networking space for advocates to meet and exchange information. ${ }^{181}$ Advocates should note that the Permanent Forum is not a complaint mechanism. ${ }^{182}$ Advocates wishing to address country-specific human rights issues should use the appropriate mechanisms of the Council.

\section{i. Membership}

Permanent Forum members are comprised of government and indigenous nominated experts who serve in their personal capacity, ${ }^{183}$ the 16 members are selected for three-year terms - eight are nominated by Member States and elected by ECOSOC and eight are nominated by indigenous organizations and appointed by the President of ECOSOC. ${ }^{184}$ The government-nominated experts are selected based on the five UN regional groups while those chosen by indigenous

\footnotetext{
177 ECOSOC Res 2000/22, 2, UN Doc E/RES/200o/22 (July 28, 200o) [hereinafter ECOSOC Res. 2000/22].

178 Ibid. 2 (a) $-(\mathrm{c})$.

179 United Nations Permanent Forum on Indigenous Issues Handbook for Participants, at 11 (May 2007), http://un-documents.net/unpfii-participants-handbook.pdf, [hereinafter Handbook for Participants].

180 Ibid.

181 Ibid. at p.12.

182 Fact Sheet on the Permanent Forum on Indigenous Issues, Indigenous Peoples' Center for Documentation, Research and Information - Docip, at 1, https:/www.docip.org/fileadmin/ documents/Docip/Fiches_pratiques/Fiches_UNPFII/EN/final_PFII_fact_sheet_EN_2018_2.pdf (last visited July 28, 2018) [hereinafter Permanent Forum Fact Sheet].

183 ECOSOC Res 2000/22, supra note 177, 1.

184. Ibid.
} 
organizations represent the seven socio-cultural regions (Africa; Asia; Central and South America, and the Caribbean; the Arctic; Central and Eastern Europe, the Russian Federation, Central Asia and Transcaucasia; North America; and the Pacific). ${ }^{185}$

Members of the Permanent Forum divide their work through the 'portfolio system', in which the experts are responsible for specific thematic areas within the Permanent Forum's mandate based on their knowledge and expertise. ${ }^{186}$ Portfolio topics can be shared between members to create better coverage and collaboration on these issues of concern. ${ }^{187}$ Advocates should consider arranging meetings with members of the Permanent Forum handling issues relevant to their advocacy. The Secretariat of the Permanent Forum on Indigenous Issues (SPFII) provides logistical support and year-round coordination to implement its mandate, including managing pre-registration of participants for its annual session. ${ }^{188}$

\section{ii. Accreditation}

Unlike the forums arising out of the Council, civil society participation at the Permanent Forum is largely limited to academic institutions and to NGOs in Consultative Status with ECOSOC. ${ }^{189}$ Indigenous peoples' organizations without Consultative Status may apply to pre-register on the Department of Economic and Social Affairs (DESA) webpage. Because there is no official UN definition of 'indigenous peoples,' SPFII's selection criteria has been criticized as overly discretionary. ${ }^{190}$

\section{iii. Work of the Permanent Forum}

In preparation for the session, the SPFII circulates a provisional programme of work one month before the session. ${ }^{191}$ The agenda includes a review of the implementations of the recommendations from the

\footnotetext{
185 Ibid.

186 Handbook for Participants, supra note 179, at p.21.

187 Ibid.

188 Ibid. at pp.9-10.

189 ECOSOC Res 2000/22, supra note $\mathbf{1 7 7}, \mathbf{9} 1$.

190 'Who Are Indigenous Peoples,' United Nations Permanent Forum on Indigenous Peoples, at p.1 http://www.un.org/esa/socdev/unpfii/documents/5session_factsheet1.pdf (last visited July 28, 2018); see also First Informal Interactive Hearing with Indigenous Peoples, President of the General Assembly, at 5, (May 31, 2018), https://www.un.org/development/desa/indigenouspeo ples/wp-content/uploads/sites/19/2018/o6/Informal-interactive-hearing-Letter-to-IndigenousPeoples-31-May.pdf.

191 Handbook for Participants, supra note 179, at p.12.
} 
previous sessions, a follow-up to the outcome document of the World Conference on Indigenous Peoples, and a discussion of issues pertaining to that year's theme. ${ }^{192}$ In 2018 , the Permanent Forum changed the structure of its sessions, dedicating the first week to open plenary meetings to address all substantive agenda items and reserving the second week to informal, closed meetings with representatives of indigenous peoples, Member States and UN entities. ${ }^{193}$ The purpose of the second week meetings is to draw on information presented during the first week and make policy recommendations that are strategic, focused, and actionable. ${ }^{194}$

The Permanent Forum's session is divided into morning and afternoon meetings as well as side events and special gatherings hosted by UN agencies, States, indigenous organizations and other nongovernmental organizations. ${ }^{195} \mathrm{~A}$ list of side events and special gatherings are posted on the Permanent Forum website one week prior to the session. Advocates pre-registered to attend the Permanent Forum who are interested in organizing a side event should contact the SPFII. ${ }^{196}$

\section{iv. Outcome of the Permanent Forum}

The outcome of each session is a report containing the Permanent Forum's draft decisions for adoption by ECOSOC as well as its recommendations to UN entities, intergovernmental organizations, indigenous peoples, the private sector and NGOs. ${ }^{197}$ Advocates should note that the decisions and recommendations of the Permanent Forum must be by consensus of its 16 members. ${ }^{198}$ Once the report is adopted, the Inter-Agency Support Group (IASG) is then mandated to, 'analyze, disseminate and contribute to the implementation of the

192 See Proposed organization of work, 17th Sess., Permanent Forum on Indigenous Issues,

Economic and Social Council, April 16-27, 2018, UN Doc E/C.19/2018/L.1 (Jan. 19, 2018), [hereinafter Proposed organization of work].

193 See UNPFII Seventeenth Session: 16-27 April 2018 United Nations Permanent Forum on Indigenous Peoples, https://www.un.org/development/desa/indigenouspeoples/unpfii-sessions2/2017-2.html, (last visited July 28, 2018), [hereinafter UNPFII 17th Session].

194. Ibid.

195 Proposed organization of work, supra note 192, at 2; see also UNPFII, List of Side Events at UNHQ 17th Session, https://www.un.org/development/desa/indigenouspeoples/wp-content/ uploads/sites/19/2018/05/UNPFII17_Side_Events_timestable_May7.pdf (last visited July 28, 2018).

196 See UNPFII, Guidelines for Organizers of Side Events, http://www.un.org/esa/socdev/unpfii/ documents/session_tenth_side_event_guidelines.doc (last visited July 28, 2018).

197 Handbook for Participants, supra note 179, at 18.

198 ECOSOC Res 2000/22, supra note $177,3$. 
recommendations of the Forum'. ${ }^{199}$ The IASG is comprised of staff members from over $40 \mathrm{UN}$ agencies and intergovernmental bodies who convene annually to analyze the Permanent Forum's recommendations with a view toward facilitating comprehensive and coordinated responses. $^{200}$

The SPFII also maintains a detailed online database of recommendations raised during previous Permanent Forum sessions. ${ }^{201}$ The database includes information on in which session the recommendation was raised, which stakeholders the recommendation addresses, directions on how the recommendation should be implemented, and the status of its implementation. ${ }^{202}$ Advocates should refer to the database when devising their own recommendations as part of their oral or written interventions and general advocacy.

\section{v. Oral statements}

Under the new structure, opportunities for participants to deliver oral interventions occur mostly in the first week. ${ }^{203}$ The speaking procedures at the Permanent Forum offer two types of methods in which participants can intervene: (1) under the advanced speakers' list; and (2) during interactive dialogues. Advocates should refer to the program of work to identify which meetings allow for oral interventions by participants and under which methods. ${ }^{204}$ Advocates should also review the posted documents related to the agenda items under which they intend to deliver their intervention prior to preparing their statement.

The advanced speakers' list is reserved for indigenous delegates, national human rights institutions and indigenous members of Parliaments. ${ }^{205}$ They may register to speak through an online portal a few weeks before the start of the session or in person at the SPFII's

\footnotetext{
199 Inter-Agency Support Group (IASG), https:/www.un.org/development/desa/indigenouspeoples/about-us/inter-agency-support-group.html (last visited July 28, 2018) [hereinafter IASG].

200 Ibid.; see also Handbook for Participants, supra note 179, at p.19.

201 United Nations Permanent Forum on Indigenous Peoples, UNPFII Recommendation Database, https://esa.un.org/unpfiidata/UNPFII_Recommendations_Database_list.asp?TargetPageNumb er $=54$ \&action $=$ goto \&lang $=\&$ orderby $=7 \&$ dir $=\&$ PageSize $=10 \&$ masterkey $=\&$ SearchField $=$ AnyF ield \&SearchOption $=$ Contains $\&$ SearchFor $=\&$ PageSizeSelect $=10$ (last visited July 28, 2018).

202 Ibid.

203 UNPFII 17th Session, supra note 193.

204 Permanent Forum Fact Sheet, supra note 182 at p.1.

205 Ibid.
} 
desk the day the agenda item is to be considered ${ }^{206}$ Agenda items with an interactive dialogue are open to all participants. The Chairperson typically announces the speaking procedures and time limits (usually three to five minutes) in advance. ${ }^{207}$ Statements co-sponsored by multiple organizations as well as statements by the indigenous caucuses are given priority on the advanced speakers' list. ${ }^{208}$

\section{vi. Written statements and reports}

Advocates may also submit written statements of no more than 5000 characters for an agenda item. ${ }^{209}$ Information on how to submit written statements can be accessed on DESA's webpage in the weeks prior to the start of the session. ${ }^{210}$ With limited opportunities to deliver oral interventions, written statements provide advocates with an opportunity to ensure that their issues and recommendations are raised and considered by Permanent Forum members. Indigenous peoples' organizations and NGOs may also submit unsolicited, full-length reports to the Permanent Forum. Those interested in doing so are asked to contact the SPFII. The deadline for these reports is typically January 31 of each year. ${ }^{211}$

\section{vii. Global Indigenous Caucus}

The Global Indigenous Caucus consists of representatives of indigenous peoples' organizations and usually convenes the weekend before the start of the session in New York. ${ }^{212}$ It represents a unique opportunity for indigenous delegates to work together on issues. ${ }^{213}$ During the two-day session, the caucus develops joints statements, position and recommendations. ${ }^{214}$ Other Indigenous Caucuses may also convene before the session. ${ }^{215}$ Indigenous organizations interested in participating at these meetings should contact the DOCIP Secretariat.

206 See Speakers List for the 2018 Session of UNPFII, https://docs.google.com/forms/d/e/1FAIp QLSdUUTv-JoYraxjabmrpgYXazo3zETwN8zHmQHVjUEQHOqdKZw/viewform (last visited July 28, 2018).

207 Permanent Forum Fact Sheet, supra note 182, at pp.1-2.

208 Ibid.

209 See UNPFII , Written Statements for the 2018 Session of the Permanent Forum on Indigenous Issues, https://docs.google.com/forms/d/e/1FAIpQLSdUUTv-JoYraxjabmrpgYXazo3zETwN8z HmQHVjUEQHOqdKZw/viewform (last visited July 28, 2018).

210 UNPFII 17th Session, supra note 193.

211 Ibid.

212 Permanent Forum Fact Sheet, supra note 182, at p.3.

213 Ibid.

214 Ibid.

215 Ibid. 


\section{c. Specialized agencies}

Specialized agencies are the bodies of the UN that focus on specific topics. They are also referred to as intergovernmental organizations (IGOs). The agencies include the ILO, UNESCO, the Food and Agricultural Organization (FAO), and the World Health Organization (WHO). These organizations are based in different cities, primarily in Europe: the ILO and WHO are based in Geneva, Switzerland. UNESCO is based in Paris, France, and the FAO is based in Rome, Italy.

This section will cover the procedures of the ILO and UNESCO as examples of how NGOs can address human rights issues through the specialized agencies.

\section{i. International Labour Organization}

The ILO was an agency of the League of Nations and became the first specialized agency of the UN in 1946. It has a unique tripartite system where governments, employers and employees participate on an equal footing in discussions and decision-making. The governing body is composed of 56 persons consisting of 28 government representatives, 14 employer representatives and 14 worker representatives. Major international trade unions have consultative status with the ILO and employers are represented by the International Organization of Employers. Participation in the various procedures, including providing information, comes primarily from governments, employers' organizations, and workers' organizations.

The ILO has adopted labour standards in over 187 conventions and 198 recommendations. The most important are those that related to: freedom of association and the right to collective bargaining; the elimination of forced or compulsory labour; the abolition of child labour; and the elimination of discrimination with respect to employment. In addition to using a State reporting procedure as is done by other treaty bodies, the ILO provides advisory services, technical assistance, and aid to victims under its International Programme for the Elimination of Child Labour.

Member States have to report on their compliance with the treaties they have ratified every five years, although certain situations such as complaints regarding gross violations of human rights would indicate that a closer examination is merited. Employers' and workers' organizations are able to provide comments at all stages of the review of 
compliance reports, although only ILO traditional partners are able to provide these comments. Employers' or workers' organizations can also trigger a shorter review if they provide information that a country is not complying with its obligations under a Convention. The written communication to the ILO can come from a local, national or international organization.

The Committee of Experts is the main body responsible for reviewing the reports from the Member States. The Committee meets for three weeks in November-December each year. The sessions are closed to the public so there is no access to NGOs, other organizations, or individuals. However, the Committee will consider information submitted from indigenous and minority organizations and concerned NGOs. Verifiable information that can be corroborated by other sources is considered. This can include reports by human rights organizations, as well as official documentation such as court proceedings, laws, and legislative texts.

The ILO also has procedures for filing complaints. For example, the ILO Committee on Freedom of Association receives complaints under the two treaties guaranteeing freedom of association: the Freedom of Association and Protection of the Rights to Organise Convention (ILO No. 87); and the Right to Organise and Collective Bargaining Convention (ILO No. 98). Trade unions and occasionally organizations of employers can file complaints regarding violations of these two treaties. Because the nature of the rights covered are deemed important, complaints against countries that have not ratified these Conventions are allowed. For example, the Committee on Freedom of Association issued a recommendation filed by the unions from the US following a ruling by the US Supreme Court that undocumented workers were not entitled to back pay for lost wages after they were illegally fired for exercising rights protected by the National Labor Relations Board, despite the fact that the US had not ratified ILO Conventions Nos. 87 and $98 .^{216}$

\section{ii. UNESCO}

The Constitution of UNESCO was issued in 1945 and came into force in 1946. While it is based in Paris, France, it also has offices in around

216 ILO Committee on Freedom of Association, Complaint against the Government of the United States presented by the American Federation of Labor and Congress of Industrial Organizations (AFL-CIO) and the Confederation of Mexican Workers, Report No. 332, Case No. 2227 (2003). 
50 countries. UNESCO promotes the rights to education, culture, right to information, freedom of thought, conscience and religion, and the right to freedom of association. Its focus on education has been to improve the quality of education often promoting educational innovation. It has promoted numerous instruments defining and protecting the right to culture, as well as the concept that all cultures form part of the common heritage of all humans. In 2001 it adopted the Universal Declaration on Cultural Diversity, which sets out the various aspects of the right to culture. ${ }^{217}$

In 1978, UNESCO established the Committee on Conventions and Recommendations which examines violations against teachers, artists, poets, authors, and scientists. Victims or persons with reliable information may file a petition. The petition requirements are similar to those of other international bodies: it must not be anonymous; it must be accompanied with sufficient evidence; it must not constitute an abuse of the right to submit communications; it must not be based exclusively on information disseminated through the mass media; it must be submitted within a reasonable time following the facts or knowledge of the alleged facts; and it must indicate what attempts have been made to exhaust domestic remedies and the decisions resulting from them. ${ }^{218}$

Before addressing admissibility of the petition, the Director-General may initiate consultations with the concerned government, which may submit a reply. The parties may appear before the Committee, which can then propose measures to the State. The procedure emphasizes friendly settlements and is confidential. Because of the secrecy, it is difficult to evaluate the benefits of the procedure. One study was able to obtain access to 64 cases involving 36 countries. It found that the situation of 93 individuals had improved as a result of the cases, but that a number of problems made the process difficult. These included that the procedure is very slow, subject to political manipulation, delayed decisions instead of reaching conclusions, accepted government responses at face value, and dismissed cases when positive results were reached. The latter included closing the case where the individual was released from prison and did not require restitution. ${ }^{219}$

\footnotetext{
217 UNESCO, 'Universal declaration on cultural diversity' adopted by the 31st Session of the General Conference of UNESCO, Paris, (Nov. 2, 2001).

218 See UNESCO Individual Complaint Procedure, http://portal.unesco.org/en/ev.php-URL_ID= 27969\&URL_DO=DO_TOPIC\&URL_SECTION=201.html.

219 Weissbrodt and de la Vega, supra note 1, at p.285.
} 
The problem may be related to the fact that the procedure was adopted in 1977 and needs to be updated.

\section{d. ECOSOC accreditation}

In order for NGOs to participate in the Charter-based procedures such as the Council and the CSW, they must be accredited by ECOSOC. Participation in the treaty-based procedures does not require accreditation but NGOs must follow their procedures to submit reports and participate in their meetings. This section will discuss the accreditation and registration requirements.

\section{i. NGO accreditation by ECOSOC}

With a few exceptions, in order to participate in the Charter-based procedures of the UN it is necessary to represent an NGO that has ECOSOC accreditation. This requirement applies to participation at the Human Rights Council and the CSW. Having ECOSOC accreditation also makes it possible to participate in meetings of bodies that might also allow registration on a one-time basis such as the treaty bodies. In general, persons with ECOSOC accreditation are permitted to enter the UN buildings in Geneva and New York when they are open. Accredited NGOs can attend meetings held in those buildings unless they are private.

ECOSOC is the body that accredits NGOs through its Committee on NGOs. The Committee meets twice a year, in January/February and May/June to review applications for Consultative Status from NGOs. ${ }^{220}$ The Committee on NGOs is the body that reviews applications from NGOs for Consultative Status. It prepares two lists from the pool of new applications. One list is granted status without much push back from NGO Committee members. This usually involves humanitarian and non-political human rights organizations such as those addressing children and disability rights. Organizations on the other list are usually questioned extensively about their work. This frequently involves organizations addressing civil and political rights and faith-based groups. The Committee rarely rejects an NGO outright but its members pose questions regarding the application for the NGO to respond to at the next session. This can delay the process of receiving

220 Committee on NGOs, NGO Branch, Dep't of Econ. and Soc. Affairs, http://csonet.org/?menu= 105 (last visited Aug. 26, 2018). 
accreditation. Some members may repeatedly pose questions in an effort to stall a final decision on the application.

Suggestions to NGOs applying for accreditation include the following:

- when completing the written application, NGOs should answer all the questions but avoid disclosing too much information with which a Committee Member State would find an issue (e.g., Armenian genocide advocacy if Turkey is on the NGO Committee).

- if an NGO believes that their application could be problematic to a Committee Member State, they should plan to attend the session in person (and be mindful of the intricate registration process to attend and access the UN premises without ECOSOC Accreditation). Those NGO representatives present at the NGO Committee's sessions have the opportunity to address the Committee directly when their application is reviewed and answer questions. Nonetheless, sometimes Committee Members can still defer an in-person response to a question for the next session, delaying a final consideration of their application. It is good to be aware that NGO Committee Member States may sometimes represent the interest of ally States in delaying consideration of an NGO's application.

- NGO representatives should meet with the State in which their organization is based to ask for their support for their application at the Committee. If the host State is not supportive of the organization's work, the NGO should seek and meet with NGO Committee Member States that would be sympathetic to the organization's mission.

- If an NGO Committee Member State seems to have an issue with an application, the NGO representative should meet with that State delegation to identify the issue at hand and try to resolve the concern outside the accreditation process.

\section{ii. Review of consultative status}

The Committee on NGOs will review the activities of accredited NGOs every four years. NGOs are required to file a Quadrennial Report for this review. The same guidelines apply to this report as with the initial application. It is important not to hide information and to report on all activities but avoid disclosing too much information. It is also 
important to use the formal UN name of a country. For example, references to Taiwan should be followed by 'Province of China' to avoid objections being raised by China. If there is an issue that is going to affect a Committee member it is a good idea to attend the meeting so any concerns can be discussed in person. This may result in some negotiations on how to move forward. For example, for purposes of on-going accreditation China might be concerned about the right to self-determination being addressed in Tibet but not about human rights issues in general in that region.

The Annual Report requires that the President/Chief Executive Officer and the Chief Administrative Officer of the NGO or Main Representative be the same for the duty offices in New York, Geneva and Vienna. The Main Representative is the person for the organization who can request accreditation for its delegates at the duty offices. Each NGO can request up to seven annual passes for each duty station but two are reserved for the President and Chief Administrative Officer. A pass from one duty station cannot be used in another. The Main Representative can request temporary passes for up to three months at each duty station. Each duty station can place limits on the number of temporary passes.

Different bodies are responsible for accreditation in Geneva and New York. It is important to check their accreditation procedures each session since they change regularly. The two bodies are:

- NGO/DPI Committee - The NGO/DPI Committee addresses NGO accreditation at the UN in New York on a yearly basis. It requires that an annual report on the NGOs' activities be filed. Again, this report should include all the activities of the NGO but avoid including too much information. The NGO/DPI Committee can place limits on the number of delegates that can be accredited to particular meetings. For example, it generally places a limit of 20 persons that can be accredited to the CSW.

- NGO Liaison Unit - The NGO Liaison Unit of UN Office in Geneva (UNOG) is the body that addresses NGO participation in Geneva. It does not require any additional reports. It also does not generally place limits on the number of delegates that can be accredited to the meetings at that venue. 


\section{B. Treaty-based procedures}

In addition to the human rights mechanisms with mandates flowing from the ECOSOC, the GA and ultimately the UN Charter, there exist a number of treaty-based bodies that monitor compliance of human rights obligations flowing from multilateral instruments. The current treaty body system evolved following the adoption of the Universal Declaration of Human Rights (UDHR) in 1945, which marked for the first ever enumeration of civil, political, economic, social and cultural rights that all human beings should enjoy. Decades later, these standards were captured into two legally binding human rights treaties: the International Covenant on Civil and Political Rights (ICCPR) and the International Covenant on Economic, Social and Cultural Rights (ICESCR). Together with the UDHR, these three instruments mark the minimum standards for human rights protection, and are referred to collectively as the International Bill of Human Rights. Over the years, several other international human rights treaties emerged focusing on certain thematic concerns or on the protection of vulnerable groups. Some treaties also expanded to include optional protocols broadening protections in a particular area or creating new mechanisms for monitoring compliance. To date, there exist nine legally-binding instruments referred to collectively as the 'core international human rights treaties' - denoting their inspiration from the provisions enshrined in the UDHR - and ten treaty bodies mandated to monitor compliance among State Parties (see Table 1.1).

This section will examine the various opportunities for advocates to engage with each of the ten UN treaty bodies. Such opportunities are not uniform since the composition and procedures of a treaty body is governed by its own rules. An effort is made to focus largely on commonalities across most of the treaty bodies and identify notable disparities wherever evident. Furthermore, only States that are party to the treaty are obligated to uphold its provisions. These obligations can be modified by State Parties through reservations made during accession or ratification. ${ }^{221}$ Before planning to raise a human rights concern with a particular treaty body, advocates should review the procedures allowed for by that treaty body. If the human rights concern is countryspecific, advocates should also review whether the State concerned is

221 Vienna Convention on the Law of Treaties Article 2(1)(d), opened for signature May 23, 1969, 1155 UNTS 331 (entered into force Jan. 27, 1980). 


\section{Table 1.1 Overview of treaty bodies' composition and procedures}

\begin{tabular}{|c|c|c|c|}
\hline Treaty Body & Corresponding Treaty & $\begin{array}{l}\text { Number of Regular } \\
\text { Sessions }\end{array}$ & $\begin{array}{l}\text { Duration of Each } \\
\text { Regular Session }\end{array}$ \\
\hline $\begin{array}{l}\text { Human Rights Committee } \\
\text { (HRC) }\end{array}$ & $\begin{array}{l}\text { International Covenant on Civil and } \\
\text { Political Rights }\end{array}$ & $\begin{array}{l}3 \text { sessions per year } \\
\text { March, July and August }\end{array}$ & Up to $4 \mathrm{w}$ \\
\hline
\end{tabular}

\begin{tabular}{|c|c|c|}
\hline $\begin{array}{l}\text { Committee on Economic, Social } \\
\text { and Cultural Rights } \\
\text { (CESCR) }\end{array}$ & $\begin{array}{l}\text { International Covenant on Economic, } \\
\text { Social and Cultural Rights }\end{array}$ & $\begin{array}{l}2 \text { sessions per year } \\
\text { May and November }\end{array}$ \\
\hline
\end{tabular}

\begin{tabular}{llll}
\hline Committee on the Elimination of & International Convention on the & 2 sessions per year & 3 weeks \\
Racial Discrimination (CERD) & $\begin{array}{l}\text { Elimination of All Forms of Racial } \\
\text { Discrimination }\end{array}$ & February and August
\end{tabular}

\begin{tabular}{|c|c|c|c|}
\hline $\begin{array}{l}\text { Committee on the Elimination of } \\
\text { Discrimination Against Women } \\
\text { (CEDAW) }\end{array}$ & $\begin{array}{l}\text { Convention on the Elimination of } \\
\text { All Forms of Discrimination Against } \\
\text { Women }\end{array}$ & $\begin{array}{l}3 \text { sessions per year } \\
\text { February, July and } \\
\text { October }\end{array}$ & 3 weeks \\
\hline
\end{tabular}

\begin{tabular}{llll}
\hline Committee on Enforced & International Convention for the & 2 sessions per year & 2 weeks \\
Disappearances (CED) & Protection of All Persons from & March and September & \\
& Enforced Disappearance &
\end{tabular}

\begin{tabular}{lll}
\hline Committee on the Rights of the & $\begin{array}{l}\text { Convention on the Rights of the } \\
\text { Child }\end{array}$ & $\begin{array}{l}3 \text { sessions per year } \\
\text { January, June and }\end{array}$ \\
Child (CRC) & September
\end{tabular}

\begin{tabular}{lll}
\hline Committee on the Rights of & Convention on the Rights of Persons & 2 sessions per year \\
Persons with Disabilities (CRPD) & 3ith Disabilities & March/April and August/ \\
& September
\end{tabular}

\begin{tabular}{|c|c|c|c|}
\hline $\begin{array}{l}\text { Committee on Migrant Workers } \\
(\mathrm{CMW})\end{array}$ & $\begin{array}{l}\text { International Convention on the } \\
\text { Protection of the Rights of All } \\
\text { Migrant Workers and Members of } \\
\text { Their Families }\end{array}$ & $\begin{array}{l}2 \text { sessions per year } \\
\text { April and September }\end{array}$ & 2 weeks \\
\hline Committee Against Torture (CAT) & $\begin{array}{l}\text { Convention against Torture and } \\
\text { Other Cruel, Inhuman or Degrading } \\
\text { Treatment or Punishment }\end{array}$ & $\begin{array}{l}2 \text { sessions per year } \\
\text { May and November }\end{array}$ & 4 weeks \\
\hline
\end{tabular}

$\begin{array}{lll}\begin{array}{l}\text { Subcommittee on the Prevention } \\ \text { of Torture (SPT) }\end{array} & \begin{array}{l}\text { Optional Protocol to the Convention } \\ \text { against Torture and other Cruel, }\end{array} & \begin{array}{l}\text { February, June and } \\ \text { Inhuman or Degrading Treatment or }\end{array} \\ & \text { November } \\ \text { Punishment }\end{array}$

Note: * These procedures are only available for State parties which have ratified the corresponding optional protocol on communication or have made the requisite declarations. 


\section{Related Optional Protocols and Declarations Granting Competency to Number of Available Procedures for Consider Communications \\ Members NGO Engagement}

Optional Protocol to the International Covenant on Civil and Political Rights 18 Second Optional Protocol to the International Covenant on Civil and Political Rights, aiming at the abolition of the death penalty

Optional Protocol to the Covenant on Economic, Social and Cultural Rights
State Reporting

Individual Communications* General Comments

State Reporting Individual Communications* General Comments Inquiry Procedure*

May consider individual communications alleging violations by States parties 18 who have made the necessary declaration under article 14 of the Convention.

\section{8}

State Reporting Individual Communications* General Comments Urgent Action
Optional Protocol to the Convention on the Elimination of Discrimination 23 against Women

\section{State Reporting} Individual Communications* General Comments Inquiry Procedure*

May consider individual communications alleging violations by States parties 10 who have made the necessary declaration under article 31 of the Convention.

State Reporting Individual Communications Inquiry Procedure General Comments Urgent Action

Optional Protocol to the Convention on the Rights of the Child on the involvement of children in armed conflict

Optional Protocol to the Convention on the Rights of the Child on the sale of children, child prostitution and child pornography

Optional Protocol to the Convention on the Rights of the Child on a communications procedure

Optional Protocol to the Convention on the Rights of Persons with Disabilities
State Reporting Individual Communications* General Comments Inquiry Procedure*
18

18

State Reporting Individual Communications* General Comments Inquiry Procedure* Individual Communications*
State Reporting

General Comments

14 parties have made the necessary declaration under article 77.
May consider individual communication alleging violations by States parties 10 who have made the necessary declaration under article 22 of the Convention. May conduct inquiries on State parties who have not made declarations reserving competency under article 28 of the Convention.

N/A
State Reporting Individual Communications General Comments Inquiry Procedure*
Visit Detention Centers

Establish National

Preventive Mechanisms 
a party to that treaty and has placed any relevant reservations which would limit its obligations.

Each treaty body consists of a committee of 10-25 unpaid, independent experts who serve in their personal capacity to monitor implementation of treaty obligations. ${ }^{222}$ They are elected by State Parties for fouryear terms during the Meeting of State parties, except for members of the CESCR, which are elected for two years during the ECOSOC's regular session. ${ }^{223}$ While treaty bodies are not formal entities under the UN Charter but derive their existence from provisions contained in separate legal instruments, they nonetheless relate to the larger UN System in three important ways: each treaty body (1) enjoys assistance from the UN Secretariat, namely the OHCHR Treaty Division and convenes at the UN Office at Geneva; (2) receives funding from the $\mathrm{UN}$; and (3) submits reports on activities to the GA through ECOSOC (except the CESCR which reports just to ECOSOC). ${ }^{224}$

Accreditation to participate in the work of UN treaty bodies is not limited to NGOs in Consultative Status with ECOSOC. Treaty bodies welcome submissions and reports from a wide variety of stakeholders including NGOs, National Human Rights Institutions (NHRIs), academics and human rights victims. Information on registering to attend treaty body sessions is prepared by the treaty body's secretariat and made available on the $\mathrm{OHCHR}$ website. ${ }^{25}$

The following sections will examine treaty body procedures which provide substantive opportunities for engagement by NGOs. Such procedures include:

- considering State reports

- adjudicating individual communications

\footnotetext{
222 UN Office of the High Comm'r for Human Rights, Human Rights Treaty Bodies and Election of Treaty Body Members, at 11 (Jan. 2013), https://www.ohchr.org/Documents/HRBodies/TB/ ElectionsGuide.pdf.

223 Except for the International Covenant on Economic, Social and Cultural Rights, which is governed by an ECOSOC resolution; See ESC Res. 1985/17, UN Doc E/Res/1985/17 (May 28, 1985).

224 Human Rights Treaty Bodies and Election of Treaty Body Members, supra note 222, at pp.6-8.

225 A Simple Guide to the UN Treaty Bodies, International Service for Human Rights, at pp.20, 41 (2015), http://www.ishr.ch/sites/default/files/documents/ishr_simpleguide_eng_final_final_ dec15.pdf.
} 
- issuing general comments

- conducting inquiries

- taking measures under early warning or urgent action procedures

- establishing national preventive mechanisms and conducting country visits.

\section{Considering State reports}

When a State ratifies a treaty, it assumes a legal obligation to report to the respective treaty body on its implementation of treaty provisions. ${ }^{226}$ This process includes submitting an initial report detailing how well the State's laws, policies and practices conform with the rights guaranteed under that treaty. ${ }^{227}$ The treaty body re-examines the State Party's compliance every two to five years, or as requested by the treaty body, through periodic reports submitted by the State. ${ }^{228}$ With the exception of the UN Subcommittee on Prevention of Torture (SPT), each of the treaty bodies engages in the State-reporting process. ${ }^{229}$

The State Party's report is prepared with support by the OHCHR and is typically organized by substantive article (or cluster of articles) of the treaty. ${ }^{230}$ As part of an on-going effort to streamline the treaty body reporting process, States have begun submitting 'Common Core Documents' alongside shorter, treaty-specific state reports. ${ }^{231}$ Common core documents are a single report covering the human rights implementation, including factual and statistical data, and a general framework for the protection and promotion of human rights, to be used across all treaty bodies..$^{232}$

\footnotetext{
226 Vienna Convention on the Law of Treaties, supra note 221, at Article (2)(1)(b).

227 OHCHR, Fact Sheet No. 30 The United Nations Human Rights Treaty System, at pp.21-22 (Aug. 2012), https://www.ohchr.org/Documents/Publications/FactSheet3oRev1.pdf.

228 Ibid. The CED only considers initial reports, not periodic reports, from State parties.

229 Ibid.

230 See Comm. on the Rights of the Child, Fifth periodic reports of States parties due in 2012 Democratic People's Republic of Korea, UN Doc CRC/C/PRK/5 (Oct. 29, 2016).

231 UN Secretary-General, Compilation of Guidelines on the Form and Content of Reports to be Submitted by State Parties to the International Human Rights Treaties: Rep. of the SecretaryGeneral, ch. I 17, UN Doc HRI/GEN/2/Rev.6 (June 3, 2009) [hereinafter Compilation of Guidelines].

232 Ibid. at p.27.
} 
Treaty bodies have also allowed State Parties to submit overdue periodic State reports with subsequent submissions together in a single 'combined report'. ${ }^{233}$ In some cases if a State Party fails to submit its report, the treaty body may elect to conduct a country review in what is called a 'review procedure'. ${ }^{234}$ Under this procedure, the treaty body examines the extent of the State's implementation of treaty provisions absent a State report, deriving its review based on information provided by NGOs, NHRIs and other UN entities. ${ }^{235}$ Typically, the threat of conducting a 'review procedure' is significant incentive for the State Party to submit an overdue report. ${ }^{236}$

The treaty body often announces the deadline for the State Party's next periodic report during the State's previous country review. ${ }^{237}$ The complete schedule of country reviews by treaty body is available on the OHCHR website. ${ }^{238}$ There is no formal mechanism at the UN level for advocates to offer input on a State report. State Parties are encouraged, however, to consult with a wide range of stakeholders, including civil society, in preparing their submission. ${ }^{239}$ If information about consultations is not readily available, advocates may consider contacting the government agency or agencies responsible for preparing the report.

Once the State Party submits its report, the treaty body begins the country review process. This process is typically divided into three phases: (1) development of the list of issues; (2) country review; and (3) the follow-up procedure.

\section{a. Development of the List of Issues}

Prior to its session, treaty bodies formulate a List of Issues (LOIs) (also known as List of Themes or List of Questions) to identify priority topics for its dialogue with the State Party. ${ }^{240}$ The LOIs takes the form of questions to the State Party based on information in its State

\footnotetext{
233 A Simple Guide to the UN Treaty Bodies, supra note 225 , at pp.17-18.

234 Ibid. at pp.21-2.

235 See Compilation of Guidelines, supra note 231, at ch. VII 18.

236 A Simple Guide to the UN Treaty Bodies, supra note 225, at pp.21-2.

237 See HRC, Concluding observations on the third periodic report of Lebanon, 51, UN Doc $\mathrm{CCPR} / \mathrm{C} / \mathrm{LBN} / \mathrm{CO} / 3$ (May 9, 2018).

238 OHCHR, 2018 Expected date of consideration, https://tbinternet.ohchr.org/_layouts/Trea tyBodyExternal/MasterCalendar.aspx?Type=Session\&Lang=En (last visited Aug. 18, 2018).

239 Compilation of Guidelines, supra note 231, at ch. I 10.

240 A Simple Guide to the UN Treaty Bodies, supra note 225, at 18.
} 
report, previous country review sessions, and submissions by NGOs, NHRIs and other stakeholders. ${ }^{241}$ Treaty bodies typically require State Parties to provide written replies to the LOI before the start of the session. $^{242}$

Some treaty bodies - namely, the HRC, CERD, CED, CMW, and CAT - draft the LOIs in preparation for their regular session. ${ }^{243}$ Others the CEDAW, CESCR, CRC, and the CRPD - convene a pre-sessional working group (PSWG) in between their plenary meetings to develop the LOIs. ${ }^{244}$ In a further effort to streamline the reporting process, the CAT, CRC, CMW, CRPD, and the HRC may elect to exercise an optional reporting procedure called the List of Issues Prior to Reporting (LOIPR). ${ }^{245}$ Under this approach, the treaty body sends its LOIs to the State Party in advance of the State's periodic report and accepts their written replies in lieu of the State report. ${ }^{246}$

Advocates can file their own submissions assessing the State Party's implementation of treaty obligations, either individually or in coalition with other NGOs. ${ }^{247}$ These reports are referred to as 'alternative reports' or 'shadow reports,' and can be submitted before and after the LOI/LOIPR is published. ${ }^{248}$ Each treaty body secretariat circulates an information note on the OHCHR website detailing the preferred format and relevant deadlines for alternative reports in advance of each regular session and PSWG meeting. ${ }^{249}$ Typically, alternative reports should be in English, follow the same structure as the State report, and be submitted electronically (some treaty bodies may also require mailing in hard copies). ${ }^{250}$ Most treaty bodies do not have strict page limits

\footnotetext{
241 Ibid. at p.39.

242 See Compilation of Guidelines, supra note 231, at ch. V $\mathbf{g}$.

243 A Simple Guide to the UN Treaty Bodies, supra note 225, at pp.18-19.

244 Ibid. at p.19.

245 OHCHR, Human Rights Treaty Bodies - Glossary of technical terms related to the treaty bodies, https://www.ohchr.org/EN/HRBodies/Pages/TBGlossary.aspx\#simplifiedrp (last visited Aug. $18,2018)$.

246 Ibid.

247 OHCHR, Working with the United Nations Human Rights Programme: A Handbook for Civil Society, 49 (2008), https://www.ohchr.org/en/AboutUs/CivilSociety/Documents/Handbook_ en.pdf [hereinafter A Handbook for Civil Society].

248 A Simple Guide to the UN Treaty Bodies, supra note 225, at pp.39-40.

249 See UN Comm. on the Elimination of Discrimination Against Women, Information Note: Participation by Non-Governmental Organizations (NGOs) (July 2018), https://tbinternet.ohchr. org/Treaties/CEDAW/Shared\%2oDocuments/1_Global/INT_CEDAW_INF_70_27225_E.docx. 250 Ibid. at pp.1-2.
} 
for alternative reports, although advocates should strive for brevity given the volume of information treaty body members must consider for each session. All submissions to the treaty body are published on the OHCHR website unless otherwise requested by the author.

Alternative reports filed before the LOI/LOIPR is published often seek to influence the treaty body's priority topics for its dialogue with the State Party and include suggested questions for the treaty body to ask the State Party. Reports filed after the State Party provides its written replies typically evaluate the State's written responses and include suggested recommendations for the treaty body to consider in preparing the outcome document of the State Party's country review. The deadlines for submissions can differ depending on whether the information is in relation to the country review, LOI, or the LOIPR. Advocates should note that, unless otherwise indicated by the author, alternative reports are made publicly available on the OHCHR website.

\section{b. Country review}

During its plenary session, the treaty body reviews the State report in a public dialogue with a delegation from the State Party under consideration. ${ }^{251}$ The aim of the dialogue is to offer the State Party an opportunity to respond to additional questions by treaty body members and provide further information in a constructive and non-judgmental fashion. ${ }^{252}$ Each State's review consists of two three-hour sessions and takes place in Palais Wilson at the UN in Geneva and is broadcast and recorded on the UN Web TV. ${ }^{253}$ The treaty body secretariat usually circulates the programme of work containing a schedule of which days each State will be examined in several weeks in advance of its session..$^{254}$

The exact format of the country review varies by treaty body but generally includes the treaty body Chairperson welcoming the State delegation, introductory remarks by the head of the State delegation, and a dialogue led by the treaty body committee member or members

\footnotetext{
251 A Handbook for Civil Society, supra note 247, at p.41.

252 Ibid.

253 UN Secretary-General, Implementation of Human Rights Instruments, 43, A/69/285; UN Web TV, http://webtv.un.org/ (last visited Aug. 22, 2018).

254 See UN Comm. on Econ., Soc. and Cultural Rights, Programme of Work 63rd session (Mar. 2018), https://tbinternet.ohchr.org/Treaties/CESCR/Shared\%2oDocuments/1_Global/INT_CE SCR_POW_63_26572_E.doc.
} 
charged with heading the country review (referred to as the country rapporteur or country task force). ${ }^{255}$

At the end of its regular session, the treaty body publishes its concluding observation for each State party it reviewed. The concluding observations contain a summary of the proceedings and identifies: (1) good practices; (2) on-going challenges; and (3) recommendations to the State Party on how to better implement its treaty obligations. ${ }^{256}$ These recommendations often focus on changes in law, policy, programmes, establishment of programmes to ensure implementations, and similar relevant measures.

Treaty bodies usually organize NGO briefings each Monday during its session. ${ }^{257}$ The briefings allow advocates the opportunity to address members on issues concerning State Parties scheduled for review later that week. Except for the CEDAW and CESCR, these sessions are closed to representatives of State Parties. ${ }^{258}$ Statements made during the briefing are simultaneously translated into other languages and are often limited to five minutes. Advocates may also request a private lunchtime briefing with treaty body members prior to the afternoon meeting when the States Party's report is scheduled for review. ${ }^{259}$ The accommodation of lunchtime briefing requests usually depends on the availability of the treaty body members. While NGOs cannot participate during the country review, some still attend the proceedings in order to meet with treaty body members after the meeting has concluded and provide additional context or correct any inaccuracies in the state delegation's replies to the treaty body's questions.

\section{c. Follow-up procedure}

All treaty bodies request State Parties to provide information in their next periodic State report on implementation of the recommendations contained in previous concluding observations. ${ }^{260}$ Some treaty bodies

\footnotetext{
255 A Simple Guide to the UN Treaty Bodies, supra note 225 , at p.20.

256 Human Rights Treaty Bodies - Glossary of technical terms related to the treaty bodies, supra note 244 .

257 See Programme of Work 63rd session, supra note 254.

258 A Handbook for Civil Society, supra note 247 , at p.53.

$259 \mathrm{OHCHR}$, Report on the working methods of the human rights treaty bodies relating to the State Party reporting process, 43, UN Doc.HRI/ICM/2011/4 (May 23, 2011).

$260 \mathrm{OHCHR}$, Follow-up to Concluding Observations, https://www.ohchr.org/EN/HRBodies/Pages/ FollowUpProcedure.aspx (last visited Aug. 18, 2018).
} 
have adopted mechanisms requiring State Parties to report back within one to two years on efforts made to realize certain recommendations considered either urgent or implementable within a short period of time. ${ }^{261}$ These 'follow-up recommendations' are identified in a paragraph at the end of the concluding observations. ${ }^{262}$ Treaty bodies typically select a minimum of three follow-up recommendations as part of the follow-up procedure. ${ }^{263}$

According to the OHCHR, to assess the follow-up report provided by the State Party, the treaty body will consider all available sources, including information originating from other treaty bodies, special procedures, the UPR, the UN system, as well as from regional human rights mechanisms. ${ }^{264}$ Treaty bodies may also invite short written submissions by NGOs, NHRIs and other stakeholders detailing measures taken by the State Party to implement the follow-up recommendations. ${ }^{265}$ The deadline for NGO written submissions is typically around one month before the beginning of the session during which the State Party's follow-up report is scheduled to be assessed. ${ }^{266}$

\section{Adjudicating individual communications}

Unlike the country review process which focuses on the general human rights situation in the State Party, individual communications provide a person with the opportunity to receive a determination of whether their rights were violated under the treaty by members of that treaty body. The process is akin to domestic legal proceedings, although its decisions are not legally binding on the State Party. ${ }^{267}$ While there are some procedural disparities among each of the treaty bodies which allow for individual communications, their design and operation are largely similar.

\footnotetext{
261 Ibid.

262 Ibid.

263 A Simple Guide to the UN Treaty Bodies, supra note 225 , at p.24.

264 Follow-up to Concluding Observations, supra note 260.

265 See UN Comm. on the Elimination of Discrimination Against Women, Information on the Follow-Up Procedure, 4 (Mar. 9, 2018), https://tbinternet.ohchr.org/Treaties/CEDAW/Shared\% 2oDocuments/1_Global/INT_CEDAW_FGD_7103_E.pdf.

266 Ibid.

267 OHCHR, Fact Sheet No. 7 Individual Complaint Procedure Under the United Nations Human Rights Treaties, 11 (May 2013), https://www.ohchr.org/Documents/HRBodies/TB/Elections Guide.pdf [hereinafter Fact Sheet No. 7].
} 
Individual communications (also referred to as a complaint or petition) can only be brought against a State that is: (1) party to the treaty and (2) has 'opted in' to the procedure. ${ }^{268}$ Depending on the treaty, States can opt in to the individual communication procedure in one of two ways: treaties overseen by the HRC, CEDAW, CRPD, CESCR, and the CRC require State Parties to ratify an optional protocol granting the treaty body the ability to consider individual communications. ${ }^{269}$ While treaties overseen by the CAT, CERD, CMW, and the CED require State Parties to make a declaration under a specific article granting the treaty body such competency. ${ }^{270}$

Typically, a communication can be lodged by either the alleged victim or her authorized representative (a lawyer is not required to file an individual communication). ${ }^{271}$ Some treaty bodies also allow for communications on behalf of a group of alleged victims (e.g., members of a racial group harmed by a State Party's discriminatory policies). ${ }^{272}$ In special circumstances, treaty bodies may accept communications on behalf an alleged victim without the victim's written consent. For instance, if the alleged victim is subject to an enforced disappearance the victim's written consent is not required. ${ }^{273}$ The CRC allows communications submitted on behalf of an alleged child victim without the child's expressed consent only if the treaty body deems it to be in the best interest of the child. ${ }^{274}$

There is no particular format that communications must follow, but advocates should refer to the model complaint forms and guidelines provided by the $\mathrm{OHCHR}$ for each treaty body when preparing their submission. ${ }^{275}$ The $\mathrm{OHCHR}$ lists the following items that should be part of any individual communication: ${ }^{276}$

268 OHCHR, Human Rights Treaty Bodies - Individual Communications, https://www.ohchr.org/ EN/HRBodies/Pages/TBGlossary.aspx\#simplifiedrp (last visited Aug. 18, 2018).

269 Ibid.

270 Ibid.

271 A Handbook for Civil Society, supra note 247 , at 55.

272 UN Comm. on the Elimination of Racial Discrimination Against Women, Rules of procedure of the Committee on the Elimination of Racial Discrimination, Rule 91(a), UN Doc CERD/C/35/ Rev.3 (1986).

273 Ibid., Rule 91(b).

274 UN Comm. on the Rights of the Child, Rules of procedure under the Optional Protocol to the Convention on the Rights of the Child on a communications procedure, Rule 13, UN Doc CRC/C/62/3 (Apr. 8, 2013).

275 Fact Sheet No. 7, supra note 267 , at pp.25-41.

276 bild. at pp.4-5. 
- submitted in one of the UN's official languages;

- include the petitioner's personal information - her or his name, nationality, date of birth, postal address and email address - and the State Party against whom the communication is against;

- if the petition is brought by someone other than the alleged victim, the petition should have the alleged victim's written authorization or an explanation as to why obtaining such written authorization is not feasible;

- contain a detailed description of the facts essential to the case, as well as copies of the all supporting documents relevant to their claims and arguments, including administrative or judicial decisions issued by national authorities;

- if the document exceeds 20 pages, the communication should provide a short summary of up to five pages highlighting its main elements;

- an analysis of how the facts alleged constitute a violation of the treaty in question and an indication of the types of remedies the petitioner seeks from the State Party;

- an explanation of how the admissibility requirements have been satisfied, including exhaustion of domestic remedies as well as other items detailed below.

After the communication is submitted, the proceedings are typically divided into four stages: (i) pre-screen and registration; (ii) consideration of admissibility; (iii) consideration on the merits; and (iv) followup. Consideration of admissibility and consideration on the merits can happen concurrently or consecutively, depending on the decision of the treaty body or at the request of the State Party. ${ }^{277}$

\section{a. Pre-screen and registration}

Submissions are initially reviewed by the OHCHR's petitions unit to determine whether the communication received contains all the

277 A Simple Guide to the UN Treaty Bodies, supra note 225 , at p.30. 
required information to move forward. ${ }^{278}$ If the communication is missing some required information, the OHCHR may contact the petitioner to address the gap. ${ }^{279}$ If the communication is sufficient, it is then transmitted to the treaty body member of the appropriate treaty body tasked with receiving new communications (referred to as the 'Special Rapporteur on new communications'). ${ }^{280}$ Based on the communication's summary, the Special Rapporteur may determine whether there exists sufficient information to register the communication. ${ }^{281}$ If so, the case is assigned a number and added to the docket of communications. ${ }^{282}$ If not, the case is archived and a reply is sent to the petitioner as to why the case did not proceed. ${ }^{283}$

\section{b. Consideration of admissibility}

A communication is deemed admissible if it satisfies the procedural elements prior to its submission. The OHCHR provides the following overview of admissibility requirements that individual communications must satisfy in order for the treaty body to consider the substance of the case: ${ }^{284}$

- the petitioner (or the person on whose behalf the communication is brought) is a victim of the violation. It is not sufficient to merely allege that the State Party's law, policy or practice in question impacts the victim in the abstract. The petitioner must point to the harm endured directly and individually by the alleged victim from that law, policy or practice.

- the communication is sufficiently substantiated and compatible with provisions of treaty invoked. The alleged violation must relate to a right actually protected by the treaty. The facts presented must be sufficient on their own to substantiate a violation of the State Party's treaty obligations.

- domestic remedies have been exhausted. Before a treaty body may consider a communication, the petitioner must show that all

\footnotetext{
278 Ibid. at 29.

279 Ibid.

280 Ibid.

281 Ibid.

282 Ibid.

283 Ibid. at p.3o.

284 Fact Sheet No. 7, supra note 267 , at pp.7-9.
} 
available procedures to seek redress for the alleged violation were pursued at the local level. This includes exhausting every stage of the State Party's national court system. A petitioner may avoid exhausting domestic remedies if she can sufficiently demonstrate that 'the application of the remedies is unreasonably prolonged or is unlikely to bring effective relief'. ${ }^{285}$

- the same matter not pending before another international body. If another treaty body or regional mechanism is considering the same matter, the individual communication may be deemed inadmissible. Such regional mechanisms include the Inter-American Commission on Human Rights, the Inter-American Court of Human Rights, the African Commission on Human and Peoples' Rights, the African Court on Human and Peoples' Rights or the European Court of Human Rights. Some treaty bodies further restrict consideration of individual communications if the same matter has been previously decided by such bodies. The Human Rights Committee has concluded that communications considered by bodies emanating from the UN Human Rights Council (e.g., the complaint procedure) do not preclude the communication's admissibility. ${ }^{286}$

- there has been no significant delay in submitting the communication. Some treaty bodies may not consider communications where more than one to five years have lapsed since the time after the exhaustion of domestic remedies or following a decision by another international body, unless the petitioner can sufficiently account for the delay.

- the case concerns matters arising after the complaint mechanism entered into force. Unless the alleged violation creates an on-going harm, treaty bodies will not consider communications alleging violations that occurred before the individual communication procedure entered into force for the State Party concerned.

- there is no reservation limiting the treaty body's competence. An individual communication will be deemed inadmissible if the treaty

285 See UN Comm. Against Torture, Rules of procedure, Rule 97, UN Doc CAT/C3/Rev.6 (Apr. 8, 2013).

286 Human Rights Comm., Celis Lauréano v. Peru, Commc'n No. 540/1993, 7.1, UN Doc CCPR/ C/56/D/540/1993 (Apr. 16, 1996). 
body is precluded from considering the complaint due to a lawful reservation placed by the State Party.

- the communication is not an abuse of the procedure. If the treaty body considers the communication as such, it may reject the complaint as inadmissible.

The State Party has around two months to provide its observations on the communication's admissibility (unless the communication's admissibility and merits are considered concurrently, at which point the State Party must respond to both aspects within such a time frame). ${ }^{287}$ The petitioner is given six weeks following the submission of the State Party's observation to provide a response. ${ }^{288}$ The treaty body may also ask the petitioner to provide further information as well. If the treaty body deems the communication inadmissible, the proceedings end and both the petitioner and State party are notified. ${ }^{289}$

\section{c. Consideration on the merits}

When considering the communication on its merits, the treaty body will seek to determine whether the State Party has violated its obligations under the applicable provision of the treaty. ${ }^{290}$ In addition to the petitioner's submission and responses and the State Party's observations, the treaty body will base its review on its own jurisprudence, authoritative interpretations of treaty provisions (known as general comments), and concluding observations from previous country review cycles. ${ }^{291}$ Advocates can access documents from past communications and their related documents across all treaty bodies through the OHCHR's jurisprudence online database. ${ }^{292}$ Some treaty bodies may also consider any documentation from organizations within the UN system that would help in the consideration of the communication. In such cases, the treaty body will grant each party an opportunity to comment on the documentation under consideration. ${ }^{293}$

\footnotetext{
287 Fact Sheet No. 7, supra note 267, at p.16. 288 Ibid.

289 A Simple Guide to the UN Treaty Bodies, supra note 225 , at p.30.

290 Fact Sheet No. 7, supra note 267 , at p.9.

291 Ibid.

292 OHCHR, Jurisprudence Database, http://juris.ohchr.org/ (last visited Aug. 18, 2018).

293 See UN Comm. on Enforced Disappearances, Rules of procedure, Rule 76(1), UN Doc CED/C/1 (June 22, 2012).
} 
A treaty body will typically not consider communications concerning matters covered by a reservation made by the State Party concerned, unless the reservation itself is deemed unlawful. ${ }^{294}$ The treaty body conducts its review of individual communications during a closed session. ${ }^{295}$ It may, in rare circumstances, invite the petitioner and the State Party to answer additional questions in person. ${ }^{296}$ Not attending an in-person hearing will not prejudice either party's case.

The State Party typically has around three months to submit observations on the merits of the case once it is deemed admissible. ${ }^{297}$ The petitioner is given six weeks to respond to the State Party's observations. If the treaty body finds no violation of the State Party's obligations, the proceedings end and both parties and petitioners are notified. ${ }^{298}$ If a breach of the State Party's obligations under the treaty is found, the treaty body issues a decision that includes recommendations to the State Party on remedying the violation. ${ }^{299}$ The decision is conveyed to the petitioner and the State Party simultaneously. ${ }^{300}$

\section{d. Follow-up}

Each treaty body that allows for the individual communication procedure designates one or more of its members to serve as the Special Rapporteur or Working Group tasked with the formal responsibility of coordinating follow-up on its recommendations. ${ }^{301}$ All follow-up information is made public and included in the treaty body's annual reports. $^{302}$

The follow-up procedure begins with a request to the State Party for information on the implementation of the treaty body's recommendations within three to six months after the decision is conveyed. ${ }^{303}$ The

\footnotetext{
294. Fact Sheet No. 7, supra note 267 , at p. 9.

295 Ibid. at p.15.

296 Rules of procedure of the Committee on the Elimination of Racial Discrimination, supra note 272 at Rule 94.(5).

297 Fact Sheet No. 7, supra note 267 , at p. 16.

298 Ibid.

299 Ibid.

300 Ibid. at p.10.

301 A Simple Guide to the UN Treaty Bodies, supra note 225, at p.29.

302 See Human Rights Comm., Report of the Human Rights Committee, gy 21-40, UN Doc A/72/40 (June 14, 2017).

303 Fact Sheet No. 7, supra note 267, at p.11.
} 
information is then communicated to the petitioner for a response. If the implementation is deemed sufficient, the follow-up procedure concludes. ${ }^{304}$ If the State Party fails to take appropriate measures to implement the recommendations, the treaty body continues a dialogue with the State Party until satisfactory measures are taken. ${ }^{305}$ In some cases, the treaty body may decide to publicize the State's non-compliance by issuing reminder letters, meeting with State representatives, and following-up during the State Party's country review. ${ }^{306}$

\section{e. Interim measures and friendly settlements}

At any point in the proceedings, the petitioner may request the treaty body to call on the State Party concerned to take 'interim measures' to prevent irreparable harm to the alleged victim. ${ }^{307}$ Such measures are usually in place, for example, to stop a planned execution or halt the deportation of a person to a country where she would face a risk of torture. ${ }^{308}$ For an interim measure to be granted, the alleged victim must show that she would suffer irreparable harm and present a case with a reasonable likelihood to succeed on the merits. ${ }^{309}$ Petitioners should submit requests for interim measures as early as necessary since it takes several days for the secretariat to process such requests. ${ }^{310}$

Following consent by both the parties and the petitioner, some treaty bodies allow for the mediation of a complaint through a confidential 'friendly settlement' procedure. ${ }^{311}$ The request for a friendly settlement may be submitted to the treaty body at any time during the procedure before a final decision is reached. ${ }^{312}$ If no friendly settlement is reached, or if either the petitioner or State Party decides to discontinue it, the treaty body will continue the examination of the complaint in

\footnotetext{
304 Ibid.

305 Ibid.

306 Ibid.

307 A Simple Guide to the UN Treaty Bodies, supra note 225, at p.30.

308 Ibid. at pp.30-31.

309 Fact Sheet No. 7, supra note 267, at p.7.

310 A Simple Guide to the UN Treaty Bodies, supra note 225, at p.31.

311 See ECOSOC, Provisional rules of procedure under the Optional Protocol to the International Covenant on Economic, Social and Cultural Rights, adopted by the Committee at its forty-ninth session, Rule 15, UN Doc E/C.12/49/3 (Jan. 15, 2013).

312 Ibid., Rule 15(2).
} 
accordance with the normal procedure. ${ }^{313}$ In all cases, a friendly settlement must be based on respect for the obligations set forth in the treaty. ${ }^{314}$

Lastly, advocates should note that since communications are made publicly available on the OHCHR website and are included as part of the treaty body's jurisprudence, requests for anonymity must be made at the earliest possible stage in order to avoid any unwanted disclosure. $^{315}$

\section{Conducting inquiries}

Treaty bodies may initiate an inquiry into well-founded allegations of serious, grave or systematic violations of human rights under the treaty by a State Party. Six treaty bodies allow for this procedure: CAT; CEDAW; CRPD; CED; CRC; and the CESCR. ${ }^{316}$ With the exception of the CED and the CAT, the procedure is only available for State Parties that have ratified the respective optional protocols on a communication procedure. ${ }^{317}$

The procedure is typically initiated when the treaty body receives reliable information indicating that the rights contained in the treaty are being systematically violated by the State Party. ${ }^{318}$ If the information presented is deemed credible, the treaty body invites the State Party to submit its observations on the allegations at issue. ${ }^{319}$ Based on the State Party's observations and other relevant information, the treaty body may designate one or more of its members to conduct an inquiry and report quickly to the treaty body. ${ }^{320}$ Where warranted and only with the consent of the State Party concerned, an inquiry may include a country visit. ${ }^{321}$ Findings and recommendations are submitted to the State Party. ${ }^{322}$ The treaty body requests the State Party to submit its

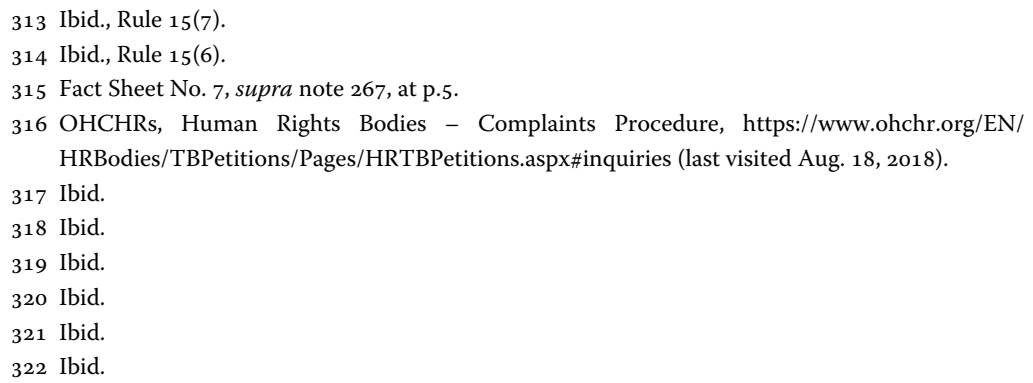


own observations on the inquiry's findings, comments and recommendations within a specific time frame (usually six months). ${ }^{323}$

All stages of the inquiry are confidential. ${ }^{324}$ Following consultations with the State Party concerned, the treaty body may decide to include a summary of the proceeding in its annual report. ${ }^{325}$ Advocates may contribute to the inquiry procedure by submitting treaty bodies with information on well-founded allegations of serious treaty violations by a State Party.

Submissions should be factual descriptions of the alleged violations based more on first-hand accounts than reports disseminated by mass media. ${ }^{326}$ They must also indicate an analysis of the rights under the treaty which are alleged to have been infringed by these violations. ${ }^{327}$ Advocates who do not wish to have their personal identity or that of their organization disclosed should include such a request in their submission. ${ }^{328}$ Further information on how to prepare a submission for the inquiry procedure can be found on the treaty body website. ${ }^{329}$

While the inquiry procedure is private and proceedings often take several years to complete, it nonetheless can be an effective tool to address grave violations of rights under the treaty. In 2005, CEDAW initiated an inquiry to investigate a high number of unsolved abductions, rapes and murders of women in Chihuahua, Mexico. ${ }^{330}$ The inquiry concluded with recommendations to Mexican authorities to improve investigations of these types of cases moving forward, focus on root causes of the crimes identified in the report, and address the impunity of those responsible. ${ }^{331}$

\footnotetext{
323 Ibid.

324 Ibid.

325 See Comm. Against Torture, Report of the Committee Against Torture, g9 58-61, UN Doc $\mathrm{A} / 72 / 44$ (2017).

326 See UN Office of the High Comm'r for Human Rights, Committee on the Elimination of Discrimination Against Women Inquiry Procedure, https://www.ohchr.org/en/hrbodies/ cedaw/pages/inquiryprocedure.aspx (last visited Aug. 18, 2018).

327 Ibid.

328 Ibid.

329 Ibid.

330 See Comm on the Elimination of Discrimination Against Women. Report of the Committee on the Elimination of Discrimination Against Women, gy 395-396, UN Doc A/60/38 (2005).

331 Comm. on the Elimination of Discrimination Against Women, Report on Mexico produced by the Committee on the Elimination of Discrimination against Women under article 8 of the
} 


\section{Issuing general comments}

With the exception of the SPT, all treaty bodies issue general comments (sometimes referred to as general recommendations) which serve as authoritative guides for State Parties on how to interpret and implement treaty provisions. ${ }^{332}$ General comments typically focus on a single article in the treaty or address a group of articles focused on a particular theme (e.g., the CERD General Recommendation No. 30 on Discrimination Against Non-Citizens). ${ }^{333}$ Treaty bodies may adopt new general comments to replace older interpretations of treaty provisions or may issue a general comment with other treaty bodies to cover cross-cutting thematic issues. ${ }^{334}$

General comments are often issued to address persistent disparities in understanding of treaty obligations by State Parties made evident over several cycles of the country review process or by the individual communications procedure. Treaty body members sometimes identify the treaty article or articles considered for the development of future general comment in their annual report. ${ }^{335}$ Prior to adopting a new general comment, treaty bodies may organize a 'general discussion day' (also referred to as thematic discussions) to examine a particular issue or concern during its regular session. ${ }^{336}$ Not all general discussion days, however, result in the development and adoption of a general comment.

In some cases, the treaty body prepares a draft of the general comment and invites all stakeholders, including State Parties, multilateral organizations and NGOs, to offer concise written comments concerning the text of the draft general comment. ${ }^{337}$ Stakeholders may use

Optional Protocol to the Convention, and reply from the Government of Mexico, 271-286, UN Doc CEDAW/C/2005/OP.8/MEXICO (2005).

332 OHCHR, Human Rights Treaty Bodies - General Comments, https://www.ohchr.org/EN/HR Bodies/Pages/TBGeneralComments.aspx (last visited Aug. 18, 2018).

333 Ibid.

334 See Human Rights Comm., General Comment No. 28 Article 3 (The equality of rights between men and women), 1, UN Doc HRI/GEN/1/Rev.9 (Mar. 29, 2000).

335 See UN Comm. on Econ., Soc. and Cultural Rights, Committee on Economic, Social and Cultural Rights Report on the sixtieth, sixty-first and sixty-second sessions, 59-6o, UN Doc E/2018/22 (2018)

336 See OHCHR, Committee on the Rights of the Child - Days of General Discussion, https://www. ohchr.org/EN/HRBodies/crc/Pages/DiscussionDays.aspx (last visited Aug. 18, 2018).

337 See Human Rights Comm. General Comment No. 36 on article 6 of the International Covenant on Civil and Political Rights, on the right to life (advance unedited version) (Mar. 29, 2000), https://www.ohchr.org/Documents/HRBodies/CCPR/GCArticle6/GCArticle6_EN.pdf. 
written submissions to raise relevant issues or concerns not included in the draft general comment or offer additional legal interpretations of treaty obligations arising out of national or regional courts and other quasi-judicial bodies. For instance, the UNHCR's written submission to the CESCR regarding draft general comment to the right of just and favorable conditions of work under Article 7 highlighted the article's application to forcibly displaced persons, including refugee women and children, based on the particular challenges such groups face in the formal and informal labor force. ${ }^{338}$

Treaty bodies may also invite stakeholders to deliver oral interventions on the draft general comment during the general discussion day. ${ }^{339}$ Additional information on how to attend general discussion days, prepare written submissions, and register to deliver oral interventions is typically posted on the treaty body website. ${ }^{340}$ General comments are often discussed and debated by treaty body members over several sessions before they are formally adopted.

\section{Taking measures under early warning and urgent action procedures}

For instances where a human rights concern creates an immediate threat to human life or liberty, certain treaty bodies have developed procedures allowing for a more prompt and timely intervention than conventional treaty body mechanisms. The CERD has adopted measures which include early-warning procedures aimed at preventing existing racial discrimination or hatred from escalating into conflict as well as urgent action procedures to respond to problems requiring immediate attention to prevent or limit the scale or number of serious violations of the treaty. ${ }^{341}$ Similarly, the CED allows for urgent action

338 OHCHR, UNHCR comments on the draft General Comment on the Right to just and favorable conditions of work (Article 7 of the International Covenant on Economic, Social and Cultural Rights), g 22-29 (May 2015), https://www.ohchr.org/Documents/HRBodies/CESCR/ Discussions/2015/UNHCR.pdf.

339 See OHCHR, Committee on Economic, Social and Cultural Rights - General discussion on a draft general comment on article 15 of the International Covenant on Economic, Social and Cultural Rights: on the right to enjoy the benefits of scientific progress and its applications and other provisions of article 15 on the relationship between science and economic, social and cultural rights, https://www.ohchr.org/EN/HRBodies/CESCR/Pages/Discussion2018.aspx (last visited Aug. 18, 2018).

340 Ibid.

341 OHCHR Committee on the Elimination of Racial Discrimination - About the Early Warning and Urgent Procedures, https://www.ohchr.org/EN/HRBodies/CERD/Pages/EarlyWarning 
procedures to address credible claims that a person has been subject to an enforced disappearance. ${ }^{342}$

\section{a. Procedures under the CERD}

Some indicators which may elicit use of the procedure by the CERD include the presence of a significant and persistent pattern of racial discrimination, as evidence in social and economic indicators, escalating racial hatred and violence or racist propaganda (especially by elected State officials), adoption of new discriminatory legislation, significant flow of refugees and displaced persons and the encroachment of indigenous lands. ${ }^{343}$ Measures the treaty body may undertake under the early warning procedure include: ${ }^{344}$

- requesting from the State Party concerned the urgent submission of information on the situation considered under the early warning and urgent action procedure;

- requesting the Secretariat to collect information from field presences of the OHCHR and specialized agencies of the UN, national human rights institutions, and NGOs on the situation under consideration;

- offering to send to the State Party concerned one or more treaty body members in order to facilitate the implementation of international standards or the technical assistance to establish a human rights institutional infrastructure;

- recommending to the State Party concerned to avail itself of the advisory services and technical assistance of the OHCHR;

- adopting a decision, including the expression of specific concerns, along with recommendations for action, addressed to various stakeholders, including the State Party concerned, relevant special procedures mandate holders and bodies of the Human Rights

Procedure.aspx\#about (last visited Aug. 18, 2018) [hereinafter About the Early Warning and Urgent Procedures].

342 GA Res 61/177, International Convention for the Protection of All Persons from Enforced Disappearance, Article 30, UN Doc A/RES/61/177 (Dec. 20, 2006).

343 Comm. on the Elimination of Racial Discrimination, Report of the Committee on the Elimination of Racial Discrimination, annex III 12, UN Doc A/62/18 (2007).

344 Ibid. 
Council, the Special Adviser of the Secretary-General on the prevention of genocide and even the Secretary-General through the High Commissioner for Human Rights, together with a recommendation that the matter be brought to the attention of the Security Council.

In deciding whether to implement such measures under the procedure, the treaty body may consider information made available to it by, inter alia, UN agencies and human rights bodies, special procedures of the Human Rights Council, regional human rights mechanisms and NHRIs and NGOs. ${ }^{345}$ Detailed guidelines for the CERD's early-warning and urgent action procedures are provided in Annex III of its 2007 report to the General Assembly. ${ }^{346}$ There are no explicit guidelines for NGO submissions, though advocates should refer to the Annex in preparing their intervention. Since 1993, the procedure has been used for more than 20 State Parties and measures undertaken include field visits and referrals to the Secretary-General, the Security Council and other relevant UN bodies. ${ }^{347}$

The early-warning and urgent action procedure can be an effective tool to garner greater attention by the State Party or the larger UN system on escalating human rights concerns or grave human rights violations. During Iraq's country review at the CERD's 85th session in August 2014, treaty body members issued Early Warning and Urgent Action Decision $1 / 85$ to address the disproportionate level of harm endured by ethno-religious minorities in Iraq soon after the fall of Mosul to the hands of the so-called Islamic State. ${ }^{348}$ The request for a decision was made by minority rights NGOs who had attended the country review and briefed treaty body members of the genocidal dimensions of the conflict. ${ }^{349}$ The Decision requested the Human Rights Council convene a special session on the human rights situation in Iraq, which later took place in September of that year. ${ }^{350}$

\footnotetext{
345 Ibid. at annex III 13 .

346 Ibid. at annex III g $1-23$.

347 About the Early Warning and Urgent Procedures, supra note 341.

348 Ibid; UN Comm. on the Elimination of Racial Discrimination, Prevention of Racial Discrimination, Including Early Warning and Urgent Action Procedures, Decision 1(85) - Iraq (advance unedited version) (Aug. 22, 2018), https://www.ohchr.org/Documents/HRBodies/ CERD/EarlyWarning/early-warningDecisionIraq.pdf. 


\section{b. Procedures under the CED}

Under Article 30 of its treaty, the CED has the power to take an urgent action against a State Party to prevent any enforced disappearance or halt its continuation. ${ }^{351}$ Those who are eligible to submit a petition for urgent action is limited to the victim's relatives, the victim's counsel (or those authorized by her or his counsel) and anyone with a legitimate interest in searching and locating the missing person. ${ }^{352}$ In order to submit a request under the procedure, petitioners must satisfy three admissibility criteria: (1) the disappearance must have occurred after the treaty has entered in force by the State Party concerned; (2) the disappearance must first be reported to a competent national authority, and if the petitioner considers that such a referral is not possible, she or he must explain why in the petition; and (3) an urgent action must not have been filed with another international procedure for the same disappearance (namely, the UN's Working Group on Enforced Disappearance). ${ }^{353}$

Urgent action requests must be submitted in writing and the identity of the victim cannot be anonymous. ${ }^{354}$ However, the name of the person or persons submitting the petition may remain confidential throughout the process. ${ }^{355}$ The petition should mention the date and circumstances of the disappearance and, if available, information on the alleged perpetrators. ${ }^{356}$ Further recommendations on what information to include in the petition along with a model submission form is available on the treaty body website..$^{357}$

The person submitting the request may also, in particularly serious cases, request the treaty body to call on the State Party to adopt interim protective measures to prevent irreparable harm to the disappeared person, or to witnesses, relatives, investigators, or defence counsel. ${ }^{358}$ The request for interim measures can be made at the initial submission

from the Permanent Representative of Iraq to the United Nations Office at Geneva addressed to the President of the Human Rights Council, UN Doc A/HRC/S-22/1 (Aug. 29, 2014).

351 GA Res 61/177, supra note 342, Article 30.

352 Ibid. Article 30(1).

353 Ibid. Article 3o(2).

354 UN Comm Against Enforced Disappearances, Guidance for the submission of a request for urgent action to the Committee, 2.3, UN Doc CED/C/4 (Apr. 29, 2014).

355 Ibid.

356 Ibid. 9 $4.1-4.7$

357 Ibid.

358 Ibid. g $3.1-3.2$ 
or anytime thereafter. ${ }^{359}$ The treaty body registers the petition for urgent action within 48 hours and transmits it to the State Party concerned. ${ }^{360}$ The State Party must then take urgent measures necessary to search for and locate the disappeared person, and to provide the treaty body with any information available as to the current status of the disappeared person. ${ }^{361}$ A complete list of registered urgent actions is available on the treaty body website. ${ }^{362}$

The State has three weeks to inform the treaty body about the current status of the disappeared person and the measures taken to search for and locate her or him. ${ }^{363}$ Given the State's response, the CED may formulate recommendations concerning the investigation of the person's disappearance. ${ }^{364}$ The CED informs the person who submitted the State Party's response and its recommendations and continues its effort to work with them and the State Party while the fate of the disappeared person remains unresolved. ${ }^{365}$

\section{Establishing national preventive mechanisms and conducting country visits (under the SPT)}

The SPT monitors the implementation of the Optional Protocol to the Convention against Torture, and Other Cruel, Inhuman or Degrading Treatment or Punishment (OPCAT). ${ }^{366}$ It functions differently from the UN's other treaty bodies. Rather than receiving State reports and adjudicating individual communications, the SPT's mandate is two-fold: (1) it advises on the implementation of the OPCAT, in particular, by helping establish, assist and monitor National Preventive Mechanisms (NPMs) at the domestic-level; and (2) it monitors conditions of detention and treatment of persons deprived of their liberty through country visits by SPT members. ${ }^{367}$

\footnotetext{
359 Ibid.

360 OHCHR, CED Leaflet: What Are Urgent Actions (Jan. 2017), https://www.ohchr.org/Docu ments/HRBodies/CED/CED_leaflet_A4_EN.pdf.

361 Ibid.

362 UN Comm on Enforced Disappearances, Urgent Actions Registered by the Committee (June 2018), https://www.ohchr.org/Documents/HRBodies/CED/list_of_urgent_actions.docx.

363 CED Leaflet: What Are Urgent Actions, supra note 360.

364 GA Res 61/177, supra note 342, Article 30(3).

365 Ibid., Article 3o(3)-(4).

366 GA Res 57/199, Optional Protocol to the Convention Against Torture and Other Cruel, Inhuman or Degrading Treatment or Punishment, Article 2(1), UN Doc A/RES/57/199 (Jan. 9, 2003), 42 ILM 26 (2003) (adopted Dec. 18, 2002) [hereinafter OPCAT].

367 Ibid. Article 11.
} 


\section{a. National preventive measures}

Article 3 of OPCAT mandates State Parties create national preventive measures (NPMs) to examine the treatment of persons deprived of their liberty, with a view to strengthening their protection against torture. ${ }^{368}$ NPMs do not engage in investigative or adjudicative activities, but work independently of government authorities to identify patterns and detect systematic risks of torture and issue recommendations to competent state officials. ${ }^{369}$

They carry out their work by visiting any places where State authorities deprive individuals of liberty, advising on national laws, policies and practices on any issues within the NPM's mandate, and strategizing on cooperation and communication with national, regional and international actors on the prevention of torture. ${ }^{370}$ NPMs also engage in educational and communication functions aimed at raising awareness of their opinions, findings, and recommendations to the general public. ${ }^{371}$ They are required to submit an annual report to the SPT providing, among other things, their most important findings and recommendations from their activities throughout the year. ${ }^{372}$ NPMs are also encouraged to submit their own reports to the other regional and human rights mechanisms (such as the UPR), expressing opinions on issues relevant to prevention of torture and ill-treatment. ${ }^{373}$

The structure and composition of NPMs vary between State Parties, but all NPMs must conform with the requirements set forth under OPCAT. ${ }^{374}$ The SPT has issued guidelines to State Parties providing further clarity regarding their basic principles, issues concerning their establishment and practical functioning. ${ }^{375}$ These guidelines also call

\footnotetext{
368 Ibid. Article 17.

369 Ibid. Articles 18-23.

370 Ibid. Articles 19-22.

371 OHCHR, Preventing Torture: A Practical Guide. Professional Training Series No. 21 The Role of National Preventive Mechanisms, 30 (2018), https://www.ohchr.org/Documents/HRBodies/ OPCAT/NPM/NPM_Guide.pdf [hereinafter Preventing Torture].

372 OPCAT, supra note 366 , Article 23.

373 Preventing Torture, supra note 371 , at p.32.

374 UN Subcomm. on Prevention of Torture and Other Cruel, Inhuman or Degrading Treatment or Punishment, Guidelines on national preventive mechanisms, 2, UN Doc CAT/OP/12/5 (Dec. 9, 2010).

375 Ibid. at pp.24-9.
} 
on State Parties to ensure civil society organizations and other stakeholders are involved in NPMs' activities. ${ }^{376}$

\section{b. Country visits}

The OPCAT allows members of the SPT the right to visit any place under the jurisdiction of a State Party where persons may endure deprivation of her or his liberty. ${ }^{377}$ This includes police stations, prisons (both military and civilian), detention centers, mental health and social care institutions. The SPT process for undertaking country visits can be broadly divided into four phases: (1) the selection of countries to be visited; (2) the preparation of the visit; (3) the conduct of the visit; and (4) follow up to the visit. ${ }^{378}$

Advocates should review the practical guide for NGOs on SPT country visits made available by the International Rehabilitation Council for Torture Victims (IRCT) for a comprehensive overview of opportunities for NGO engagement. ${ }^{379}$

\section{i. Preparing a list of countries to visit}

The SPT determines which countries it plans to visit during its November session in Geneva. ${ }^{380}$ In making its selection, the SPT members will consider: (i) whether the State Party has implemented a functioning NPM; (ii) the geographic distribution of countries previously visited (additionally, the SPT will strive to not duplicate the work of other torture monitoring mechanisms such as the Council of Europe's Committee for the Prevention of Torture); (iii) the size and complexity of the State Party; and (iv) any reports of urgent issues relating to the prevention of torture. ${ }^{381}$

Advocates may submit information to the SPT in advance of its annual session in order to provide members with better evidentiary basis for

\footnotetext{
376 Ibid. at p.16.

377 OPCAT, supra note 366, Article 1.

378 Ibid. Article 11(a).

379 Working with the UN Subcommittee on Prevention of Torture: A practical guide for NGOs engaging with the process of SPT country visits, Int'l Rehabilitation Council for Torture Victims, (Apr. 2012) https://irct.org/assets/uploads/pdf_20161120154901.pdf [hereinafter Working with the UN Subcommittee on Prevention of Torture].

380 Ibid. at p.9.

381 Ibid.
} 
making their country selection. ${ }^{382}$ This information can include an updated description of the situation in places of detention, a description of on-going efforts to improve conditions of detention and an outline of how a visit by the SPT is expected to improve the situation, and details on whether it is better to have a full monitoring visit or focus a country visit on a specific aspect of SPT's mandate (e.g., NPM establishment). ${ }^{383}$ Such information should be short, concise and submitted by September in order to allow the SPT Secretariat enough time to process the information before the treaty body's November session. ${ }^{384}$

\section{ii. Preparing for a country visit}

Following its November session in Geneva, the SPT publishes its schedule of countries to visit for the upcoming year. ${ }^{385}$ The SPT Secretariat prepares briefs for members containing background information on each State Party in line for a visit. ${ }^{386}$ The background information is derived from a variety of information including other UN bodies, special procedures of the Human Rights Council, NHRIs and NGOs. ${ }^{387}$

At this stage, NGOs can submit to the SPT information focused on the situation in places of detention or on the broader topic relating to the prevention of torture and ill-treatment in those countries to be visited that year. According to IRCT, this information can include: ${ }^{388}$

- legal or institutional framework for the protection of detainees and accountability for torture and ill-treatment;

- access to basic legal safeguards such as a lawyer and doctor of one's own choosing;

- physical and psychological conditions in places of deprivation of liberty, including detention;

- specific practices of torture and ill-treatment in places of detention;

- places or practices of particular concern;

\footnotetext{
382 Ibid. at p.10.

383 Ibid.

384 Ibid.

385 Ibid.

386 Ibid.

387 Ibid.

388 Ibid. at pp.10-11.
} 
- the existence of secret places of detention;

- the existence of a functioning NPM or the process towards its establishment.

\section{iii. During a country visit}

A country visit will typically last about ten days and include a delegation of at least two of the SPT's 25 members. ${ }^{389}$ During their visits, the SPT members will organize meetings with officials from a wide variety of government agencies and NGOs in order to obtain different varying viewpoints on the situation in that country. ${ }^{390}$ Typically, NGO meetings are arranged together with all relevant civil society representatives. ${ }^{391}$ The SPT members may convene private meetings with representatives from NGOs if circumstances warrant such a meeting (i.e., due to security concerns or the need to keep information confidential). ${ }^{392}$

In order to influence the agenda, NGOs should share relevant information related to the meeting before the visit takes place. ${ }^{393}$ Additionally, NGOs should reserve the meeting time to provide the SPT members with updates on their reports, rather than reiterating information already presented. ${ }^{394}$ Lastly, sufficient time should be reserved during the meeting to allow the SPT members to ask clarifying questions and engage in meaningful dialogue with NGOs. ${ }^{395}$

\section{iv. Following a country visit}

After a country visit concludes, the SPT conducts a confidential briefing with the State Party's government representatives and issues a press release detailing the places of detention visited. ${ }^{396}$ Soon after, the SPT prepares a report containing its findings and includes recommendations on ways the State Party can improve protection against torture and ill-treatment. ${ }^{397}$ The SPT will then request the State Party to respond within six months of receiving the report on efforts taken

\footnotetext{
389 OHCHR, The SPT in Brief, https://www.ohchr.org/en/hrbodies/opcat/pages/brief.aspx (last visited Aug. 18, 2018).

390 Ibid.

391 Working with the UN Subcommittee on Prevention of Torture, supra note 379, at p.12.

392 Ibid.

393 Ibid.

394 Ibid. at p.13.

395 Ibid.

396 Ibid.

397 Ibid.
} 
to implement the recommendations. ${ }^{398}$ Based on the response, the SPT may request a follow-up visit. ${ }^{399}$

Since the country visit process is confidential, substantive findings from the visit will not be made publicly available unless otherwise requested by the State Party. ${ }^{400}$ The publication of reports is necessary to ensure that all stakeholders, including NGOs, are able to support implementation of the report's recommendations and hold the State Party accountable for the situation in detention centers. According to the IRCT, from 2007-12 approximately 50 per cent of governments opted to publicize reports from the SPT following country visits. ${ }^{401}$ In rare situations where the State Party fails to take steps to improve the situation in light of SPT's recommendations, the SPT may request that the CAT publish its country visit report or to make a public statement. ${ }^{402}$

If the State Party decides to not publicize the SPT's report, advocates can use a variety of tactics to persuade government officials otherwise. For instance, advocates may seek access to the report through domestic access to information laws, or ensure regional and international human rights bodies request the release of the report during its examination of the State Party (e.g., as part of the UPR or treaty body country review process). ${ }^{403}$ Advocates can submit their own follow-up information to the SPT providing general updates on whether the situation in detention facilities has changed after the visit. ${ }^{404}$ If the report is publicized, information by advocates can focus on the implementation of the SPT's recommendations. ${ }^{405}$ In such cases, NGOs may decide to wait until the six-month deadline for the State Party's reply to the report's recommendations before delivering follow-up information. ${ }^{406}$ This approach will allow advocates the opportunity to also scrutinize the State Party's responses.

\footnotetext{
398 Ibid. at p.7.

399 Ibid. at p.13.

400 UN Subcomm. on Prevention of Torture and Other Cruel, Inhuman or Degrading Treatment or Punishment, Rules of procedure, rule 21, UN Doc CAT/OP/3 (Feb 22, 2013).

401 Ibid. at p.13.

402 The SPT in Brief, supra note 389.

403 Working with the UN Subcommittee on Prevention of Torture, supra note 379, at p.14.

404. Ibid. at p.15.

405 Ibid.

406 Ibid. at pp.15-16.
} 


\section{Appendix}

Basic international human rights treaties and their optional protocols

International Covenant on Economic, Social and Cultural Rights (ICESCR), GA Res 2200A (XXI), 21 GAOR Supp (No 16) at 49, UN Doc A/6316 (1966), 993 UNTS 3, entered into force, January 3, 1976.

Optional Protocol to the Covenant on Economic, Social and Cultural Rights, HRC Res 8/2, UN Doc /HRC/8/2 (2008).

International Covenant on Civil and Political Rights (ICCPR), GA Res 2200A (XXI), 21 UN GAOR Supp (No 16) at 52, UN Doc A/6316 (1966), 999 UNTS 171, entered into force March 23, 1976.

Optional Protocol to the International Covenant on Civil and Political Rights, GA Res 2200A (XXI), 21 GAOR Supp (No 16) at 59, UN Doc A/6316, 999 UNTS 302, entered into force March 23, 1976.

Second Optional Protocol to the International Covenant on Civil and Political Rights, Aiming at Abolition of the Death Penalty, GA Res 44/128, 44 UN GAOR Supp (No 49) at 207, UN Doc A/44/49, entered into force July 11, 1991.

International Convention on the Elimination of All Forms of Racial Discrimination (CERD), 660 UNTS 195, entered into force Jan. 4 1969.

Convention on the Elimination of All Forms of Discrimination Against Women (CEDAW), GA Res 34/180, UN GAOR Supp (No 46) at 193, UN Doc A/34/18o, entered into force Sept. 3, 1981.

Optional Protocol to the Elimination of All Forms of Discrimination Against Women, GA Res 54/4, annex, 54 GAOR Supp (No 49) at 5, UN Doc A/54/49 (Vol. I) (2000), entered into force Dec. 22, 2000.

Convention Against Torture and Other Cruel, Inhuman or Degrading Treatment or Punishment (CAT), GA Res 39/46, annex, 39 UN GAOR Supp (No 51) at 197, UN Doc A/39/51 (1984), entered into force June 26, 1987. 
Optional Protocol to the Convention Against Torture and Other Cruel, Inhuman or Degrading Treatment or Punishment, GA Res A/ RES/57/199, entered into force June 22, 2006.

Convention on the Rights of the Child (CRC), GA Res 44/25, annex, 44 UN GAOR Supp (No 49) at 167, UN Doc A/44/49 (1989), entered into force September 2, 1990.

Optional Protocol to the Convention on the Rights of the Child on the Involvement of Children in Armed Conflicts, GA Res 54/263, Annex I, 54 UN GAOR Supp (No 49) at 7, UN Doc A/54/49 (2000), entered into force February 12, 2002.

Optional Protocol to the Convention on the Rights of the Child on the Sale of Children, Child Prostitution and Child Pornography, GA Res. 54/263, Annex II, 54 U.N. GAOR Supp. (No. 49) at 6, U.N. Doc $\mathrm{A} / 54 / 49$, Vol. III (2000), entered into force January 18, 2002.

International Convention for the Protection of All Persons from Enforced Disappearances (CED), GA Res 61/177, UN Doc A/ RES/61/177 (2006), adopted Dec. 20, 2006.

International Convention on the Promotion and Protection of the Rights and Dignity of Persons with Disabilities (CRPD), GA Res 61/106, Annex I, UN GAOR, 61st Sess., Supp. No. 49, at 65, UN Doc A/61/49 (2006), entered into force May 3, 2008.

First Optional Protocol, International Convention on the Protection and Promotion of the Rights and Dignity of Persons with Disabilities, GA Res 61/106, Annex II, UN GAOR, 61st Sess., Supp (No 49) at 80, UN Doc A/61/49 (2006), entered into force May 8, 2008.

International Convention for the Protection of the Rights of All Migrant Workers and Their Families (CMW), GA Res 45/158, annex, 45 UN GAOR Supp (No 49A) at 262, UN Doc A/45/49 (1990), entered into force July $1,2003$. 